\title{
COMMENTARIES AND REVIEWS
}

This section of Journal of Materials Research is reserved for papers which are comments on topics of current interest or reviews of literature in a given area.

\section{Chemical corrosion of highly radioactive borosilicate nuclear waste glass under simulated repository conditions}

\author{
Lars Werme \\ Swedish Nuclear Fuel and Waste Management Company \\ Inga $\mathrm{K}$. Björner \\ Studsvik $A B$, Sweden \\ Gerhard Bart and Hans U. Zwicky \\ Paul-Scherrer-Institut, Switzerland \\ Bernd Grambow and Werner Lutze \\ Hahn-Meitner-Institut Berlin, Federal Republic of Germany \\ Rodney C. Ewing \\ The University of New Mexico \\ Claude Magrabi \\ British Nuclear Fuels, plc., United Kingdom
}

(Received 12 September 1989; accepted 5 February 1990)

This review summarizes the results of the joint Japanese (Central Research Institute of Electric Power Industry, CRIEPI, Tokyo), Swiss (National Cooperative for the Storage of Radioactive Waste, NAGRA, Baden), Swedish (Swedish Nuclear Fuel and Waste Management Company, SKB, Stockholm) international 'ISS' project on the determination of the chemical durability of the French nuclear waste borosilicate glass, which was completed in 1988. Radioactive and nonradioactive glass specimens were investigated. A data base was created with results from glass corrosion tests performed with different water compositions, $\mathrm{pH}$ values, temperatures, sample surface areas $(S)$, solution volumes $(V)$, and flow rates. Glass corrosion tests were performed with and without bentonite and/or steel corrosion products present. Variation of the glass composition was taken into account by including the borosilicate glass ' $\mathrm{MW}$ ' in the investigations, formulated by British Nuclear Fuels, plc. An understanding was achieved of the glass corrosion process in general, and of the performance of the French glass under various potential disposal conditions in particular. A special effort was made to establish a corrosion data base, using high $S / V$ ratios in the experiments in order to understand the glass durability in the long term.

A computer program, GLASSOL, was developed, based on a dissolution-precipitation model, to calculate the glass water reaction. Fair agreement between observations and the model calculations was achieved. Use of a constant (time-independent) long-term rate was justified by observations on naturally altered basaltic glasses of great age, which were compatible with what was inferred from experiments with nuclear waste glasses in the laboratory. A fractured glass block would not be altered within 10000 years at $90{ }^{\circ} \mathrm{C}$ (flow rate $<100 \mathrm{~L} /$ year). It is unlikely, however, that for long-term contact with groundwater the glass block would remain intact for time periods longer than one million years under repository conditions. The long-term rate controls the release of soluble elements, whereas that of sparingly soluble glass constituents was lower and was controlled by the groundwater flow rate. The chemical effect of bentonite on glass durability was minor, but sorption of specific elements such as Cs reduced their concentrations in groundwater. The effect of magnetite depended on the corrosion rate of the steel canister and/or the rate of iron silicate formation or multi-layer silica sorption. 


\section{INTRODUCTION}

Vitrification is the most developed method for the immobilization of high-level waste from reprocessing nuclear reactor fuel. Wastes from gas graphite reactors have been vitrified by COGEMA at 'Atelier de Vitrification de Marcoule' (AVM), France, and a vitrification plant 'Atelier de Vitrification de La Hague' (AVH) for light water reactor wastes is under construction. The glass, designated R7T7, to be produced at La Hague has been characterized by Commissariat à l'Energie Atomique (CEA), Valrho, Marcoule, France. Based on the data acquired by CEA, COGEMA guarantees the waste form integrity and stability during intermediate storage. However, final geologic disposal of the AVH glass will eventually take place and several different geologic media are considered, such as granite, clay, and salt. Therefore, the stability of the glass in potential disposal environments requires further study.

This review summarizes the results of the joint Japanese (Central Research Institute of Electric Power Industry, CRIEPI, Tokyo), Swiss (National Cooperative for the Storage of Radioactive Waste, NAGRA, Baden), Swedish (Swedish Nuclear Fuel and Waste Management Company, SKB, Stockholm) international JSS project on the determination of the chemical durability of the R7T7 glass, which was completed in 1988. Experiments were performed with glass samples closely simulating the nominal R7T7 composition. Radioactive and nonradioactive specimens were investigated. The radioactive glass, designated JSS-A, and an inactive R7T7 glass were provided by COGEMA, while another inactive glass also simulating the nominal R7T7 composition, named ABS 118, was produced by Studsvik Energiteknik AB, Studsvik, Sweden. Most of the experimental work was performed at Studsvik and at the Paul-Scherrer Institut (PSI), formerly Eidgenössisches Institut für Reaktorforschung (EIR), Würenlingen, Switzerland. Volcanic (basalt) glasses, as analogues for borosilicate nuclear waste glasses, were examined at The University of New Mexico, Albuquerque, NM, to study the long-term performance of glass in aqueous media. Chemical modeling of the glass corrosion process was performed at the Hahn-Meitner-Institut Berlin, Germany.

The project was divided into five phases. In phases I to $I V,^{1-5}$ radioactive glass was compared with nonradioactive glass. A data base was created with results from glass corrosion tests performed with different water compositions, $\mathrm{pH}$ values, temperatures, sample surface areas, solution volumes, and flow rates. Corrosion tests were performed with and without bentonite and/or steel corrosion products present. The number of results was large enough to achieve an understanding of the glass corrosion process in general, and of the per- formance of glass R7T7 under various potential disposal conditions in particular. In phase IV, an effort was made to interpret the results in terms of a first order dissolution-precipitation reaction with the concentration of silicic acid in solution controlling the rate of reaction. However, it was not possible to derive a sufficiently accurate long-term corrosion rate to extrapolate results, because the relatively low glass surface area $(S)$ to solution volume $(V)$ ratios prevented silica saturation from being achieved in the time scale available for the experiments. Work in phase $\mathrm{V},{ }^{6,7}$ the final phase of the project, was, therefore, concentrated on establishing a long-term corrosion data base for the COGEMA-type glasses, using high $S / V$ ratios in the experiments. Also, another inactive glass, termed $\mathrm{MW}$, having a different composition from the COGEMA glass, was included in the project. The MW glass was formulated by British Nuclear Fuels, plc. (BNFL), and BNFL participated in the experimental work. Finally, the investigation of alteration phenomena of basaltic glasses was a part of phase V. At the end of the project, the data base created in phases I to $\mathrm{V}$ was used for an assessment of the long-term performance of glass JSS-A in a granitic environment under potential repository conditions. ${ }^{30}$

\section{EXPERIMENTAL}

The performance of the glasses has been evaluated by studying the corrosion process in aqueous solutions as a function of variables listed in Table I. Waste package materials (such as steel corrosion products and bentonite), various fluid compositions, and granite have been included as variables, because they can have an influence on the glass corrosion process. A characterization of the bentonite and of the steel corrosion products used, as well as of the composition of the silicate water, granitic groundwater, and bentonite pore-water can be found elsewhere. ${ }^{8}$ The glasses R7T7, JSS-A, and ABS-118 were each subjected to the full range of the variables in Table I, whereas, for the glass MW, only the effects of temperature, time, and $S / V$ were investigated. The compositions of the glasses are given in Table II. The activities of the radioactive constituents in glass JSS-A are listed in Table III. Sample preparation techniques and corrosion procedures complied with guidelines recommended by the Materials Characterization Center (MCC). Static corrosion experiments closely followed the MCC $1 \mathrm{P}^{9}$ while experiments in flowing solutions followed the MCC $4^{10}$ test procedure. Monolithic specimens weighed $0.6 \mathrm{~g}$ each and were cut from cylindrical blocks, typically $85 \mathrm{~mm}$ in diameter and $120 \mathrm{~mm}$ long. Each sample measured $9 \times 9 \times 3 \mathrm{~mm}$. Radioactive specimens had a total activity of $4 \cdot 10^{9} \mathrm{~Bq}$. The specific activity of the glass was in the order of $10^{13} \mathrm{~Bq} / \mathrm{L}$, corresponding to the activity of a full scale AVH glass after 100 years. The plutonium oxide con- 
TABLE I. Variables, ranges, and materials used in glass corrosion experiments.

\begin{tabular}{|c|c|}
\hline Variables & Ranges and materials \\
\hline Glass composition & $\begin{array}{l}\text { Simulated fission products in glasses ABS 118, R7T7, and MW; radioactive fission products in glass JSS-A } \\
\left(10^{13} \mathrm{~Bq} / \mathrm{L}\right)\end{array}$ \\
\hline $\begin{array}{l}\text { Shape of glass } \\
\text { specimens (i.e., } \\
\text { surface area) }\end{array}$ & Monoliths $(9 \times 9 \times 3 \mathrm{~mm})$ and glass powders of various average grain sizes between $71 \mu \mathrm{m}$ and $160 \mu \mathrm{m}$ diameter \\
\hline $\begin{array}{l}\text { Glass surface area } \\
\text { to solution volume } \\
\text { ratio }(S / V)\end{array}$ & $10 \mathrm{~m}^{-1}$ to $4000 \mathrm{~m}^{-1}$ \\
\hline $\begin{array}{l}\text { Waste package } \\
\text { components }\end{array}$ & $\begin{array}{l}\text { Bentonite (bentonite/water weight ratio: } 0.001 \text { to } 1.5) \text {; steel corrosion products } \mathrm{Y}(\mathrm{Y}=\text { magnetite or FeOOH), } \\
\text { Y/water weight ratio: } 0.001 \text { to } 1.5\end{array}$ \\
\hline Host rock & Granite (granite/water weight ratio: 0.2 to 2 ) \\
\hline Time & 3 days to 1 year \\
\hline Temperature & $40^{\circ}$ to $110^{\circ} \mathrm{C}$ \\
\hline Leachant & De-ionized water with and without $\mathrm{CO}_{2}$, silicate water, granitic groundwater, bentonite water \\
\hline Flow rate & Static to $0.15 \mathrm{~L} /$ day \\
\hline $\mathrm{pH}$ & 2 to 10 \\
\hline
\end{tabular}

tent was increased to $0.22 \%$ to increase alpha radiation to a realistic level. The dose rate at a distance of $50 \mathrm{~cm}$ was about $0.5 \mathrm{~Gy} / \mathrm{h}$ per specimen. Due to this high radiation dose rate, the typical MCC Teflon ${ }^{\mathrm{TM}}$ containers ${ }^{9}$ were substituted for gilded stainless steel containers in all experiments where radioactive glass was used. Also, because of the strong radiation and the presence of plutonium in the glass, experiments with radioactive specimens were performed in an alpha-tight lead cave. Atomic emission spectroscopy with an inductively coupled plasma source (ICP), atomic absorption spectroscopy (AA), ion chromatography (IC), and $\alpha, \gamma$ nuclear spectroscopy were the major techniques for solution analyses. Secondary ion mass spectrometry (SIMS) was used to determine semiquantitative concentration depth profiles across the surface layers of corroded glass. ${ }^{11}$

Solution analyses provided reproducible results (variance of $5 \%$ for tests in de-ionized water with and without magnetite present, $10 \%$ for tests performed in the presence of bentonite). Ultrafiltration of solutions was performed through $1.8 \mathrm{~nm}$ filters, which showed that the formation of colloids was insignificant for silica, but was significant for actinoids. Surface analyses by SIMS, performed on monolithic samples, provided results which were, in most cases, consistent with the results from solution analyses. ${ }^{11}$

\section{EXPERIMENTAL RESULTS}

In this section experimental data and other empirical findings are reported which constitute the data base for the application and refinement of a model ${ }^{5,34}$ for quantitative description of the glass corrosion process. Figures 1(a) and 1(b) show data from two different experiments with glasses JSS-A and ABS 118, respectively, in a static system at $90{ }^{\circ} \mathrm{C} .{ }^{4}$ In both figures normalized elemental mass loss values $\left(N L_{\mathrm{i}}, \mathrm{i}=\mathrm{B}, \mathrm{Li}\right.$, $\mathrm{Mo}, \mathrm{Si}$, etc.) have been plotted as a function of time. $N L$ values were calculated by multiplying a solution concentration ' $i$ ' by $V / S$ and dividing by the mass fraction of ' $i$ ' in the glass. When the glass is congruently dissolved, $N L_{\mathrm{i}}$ values for all elements are alike and equal to the normalized total mass loss of the glass. Selective leaching would lead to higher $N L_{\mathrm{i}}$ values. Lower $N L_{i}$ values result when a surface layer forms or when the element precipitates elsewhere in the system. Dissolution of the network structure of glass JSS-A is obvious from Fig. 1(a), because the NL values for B, a network former, and $\mathrm{Na}$, a network modifier, are alike at any time. At the low $S / V$ ratio $\left(10 \mathrm{~m}^{-1}\right)$, the data for $\mathrm{Si}$ and the more soluble elements, $\mathrm{Li}, \mathrm{B}, \mathrm{Na}$, and $\mathrm{Mo}$, are equal in the beginning of the corrosion process ( $\leqslant 28$ days). Then, Si saturates in the leachate and the corrosion rate drops for all elements. The solid curves shown in Figs. 1, 3(a), 3(b), 4, and 5 have been calculated using the data in Tables V and VI, as will be explained in Sec. IV and Sec. V. A. The release of the other elements continues at a low but measurable rate at silica saturation. This is particularly evident from experiments performed at a high $S / V$ ratio $\left(1100 \mathrm{~m}^{-1}\right)$, Fig. 1(b). In this case, the volume is small and the solution quickly saturates with respect to $\mathrm{Si}$ and, for most of the time, the release of the other elements takes place in a silica saturated solution. In all experiments with COGEMA-type glasses, silica saturation in solution was attained in less than 91 days at $90^{\circ} \mathrm{C}$. A long-term corrosion rate $r_{\infty}=0.0017 \mathrm{~g} \cdot \mathrm{m}^{-2} \mathrm{~d}^{-1}$ was calculated by linear regression.

Before silica saturation, the corrosion process can be described in terms of a first order dissolution reaction. ${ }^{5}$ At infinite dilution of silica in solution the glass corrodes at its maximum rate, the 'forward rate' $k_{+}$, which was calculated to be $1.5 \mathrm{~g} \cdot \mathrm{m}^{-2} \mathrm{~d}^{-1}$ for glass JSS- 
TABLE II. Composition of simulated (i.e., nonradioactive) and radioactive nuclear waste glasses (weight percent) used in this work.

\begin{tabular}{|c|c|c|c|c|c|}
\hline Oxide & $\begin{array}{c}\text { JSS-A } \\
\text { nominal }\end{array}$ & $\begin{array}{l}\text { ABS-118 } \\
\text { nominal }\end{array}$ & $\begin{array}{c}\mathrm{R} 7 \mathrm{~T} 7 \\
\text { nominal }\end{array}$ & $\begin{array}{c}\text { MW } \\
\text { nominal }\end{array}$ & $\begin{array}{c}\text { MW } \\
\text { analyzed }\end{array}$ \\
\hline $\mathrm{Ag}_{2} \mathrm{O}$ & 0.03 & 0.02 & 0.03 & 0.02 & $\ldots$ \\
\hline $\mathrm{Al}_{2} \mathrm{O}_{3}$ & 4.87 & 4.91 & 4.91 & 5.33 & 5.34 \\
\hline $\mathrm{B}_{2} \mathrm{O}_{3}$ & 14.40 & 14.02 & 14.02 & 16.65 & 16.30 \\
\hline $\mathrm{BaO}$ & 0.60 & 0.58 & 0.60 & 0.57 & 0.56 \\
\hline $\mathrm{CaO}$ & 4.01 & 4.04 & 4.04 & $\cdots$ & $\cdots$ \\
\hline $\mathrm{CdO}$ & 0.03 & 0.03 & 0.03 & 0.02 & $\ldots$ \\
\hline $\mathrm{CeO}_{2}$ & 0.96 & 0.99 & 0.98 & 1.02 & 0.98 \\
\hline $\mathrm{CoO}$ & 0.12 & $\ldots$ & 0.03 & $\ldots$ & $\ldots$ \\
\hline $\mathrm{Cr}_{2} \mathrm{O}_{3}$ & 0.50 & 0.51 & 0.51 & 0.41 & 0.41 \\
\hline $\mathrm{Cs}_{2} \mathrm{O}$ & 1.41 & 1.10 & 1.42 & 1.13 & 0.99 \\
\hline $\mathrm{Eu}_{2} \mathrm{O}_{3}$ & $\cdots$ & $\cdots$ & $\ldots$ & 0.04 & $\cdots$ \\
\hline $\mathrm{Gd}_{2} \mathrm{O}_{3}$ & $\ldots$ & $\ldots$ & $\ldots$ & 0.02 & $\ldots$ \\
\hline $\mathrm{Fe}_{2} \mathrm{O}_{3}$ & 2.89 & 2.91 & 2.91 & 2.69 & 2.61 \\
\hline $\mathrm{La}_{2} \mathrm{O}_{3}$ & 0.89 & 0.89 & 0.90 & 0.52 & 0.51 \\
\hline $\mathrm{Li}_{2} \mathrm{O}$ & 1.97 & 1.98 & 1.98 & 3.79 & 3.70 \\
\hline $\mathrm{MgO}$ & 0.04 & 0.04 & $\cdots$ & 5.85 & 5.22 \\
\hline $\mathrm{MnO}_{2}$ & 0.71 & 0.97 & 0.72 & $\cdots$ & $\cdots$ \\
\hline $\mathrm{MoO}_{2}$ & 1.69 & 2.05 & 1.70 & 1.76 & 1.76 \\
\hline $\mathrm{Na}_{2} \mathrm{O}$ & 9.79 & 9.86 & 9.86 & 8.10 & 8.35 \\
\hline $\mathrm{Nd}_{2} \mathrm{O}_{3}$ & 1.58 & 1.52 & 1.59 & 1.61 & 1.54 \\
\hline $\mathrm{NiO}$ & 0.74 & 0.86 & 0.74 & 0.27 & 0.27 \\
\hline $\mathrm{P}_{2} \mathrm{O}_{5}$ & 0.48 & 0.28 & 0.28 & 0.18 & 0.08 \\
\hline $\mathrm{Pr}_{6} \mathrm{O}_{11}$ & 0.44 & 0.49 & 0.44 & 1.02 & 0.47 \\
\hline $\mathrm{PuO}_{2}$ & 0.22 & $\cdots$ & $\cdots$ & $\cdots$ & $\cdots$ \\
\hline $\mathrm{Rb}_{2} \mathrm{O}$ & $\cdots$ & $\cdots$ & $\ldots$ & 0.13 & $\cdots$ \\
\hline $\mathrm{SO}_{4}$ & $\cdots$ & $\cdots$ & $\ldots$ & 0.07 & 0.06 \\
\hline $\mathrm{Sb}_{2} \mathrm{O}_{3}$ & 0.01 & 0.01 & 0.01 & 0.01 & $\cdots$ \\
\hline $\mathrm{SeO}_{2}$ & $\cdots$ & $\cdots$ & $\cdots$ & 0.03 & $\cdots$ \\
\hline $\mathrm{SiO}_{2}$ & 45.12 & 45.48 & 45.48 & 46.20 & 47.10 \\
\hline $\mathrm{Sm}_{2} \mathrm{O}_{3}$ & & & & 0.32 & 0.31 \\
\hline $\mathrm{SnO}$ & 0.02 & 0.02 & 0.02 & 0.02 & $\ldots$ \\
\hline $\mathrm{SrO}$ & 0.33 & 0.33 & 0.33 & 0.36 & 0.35 \\
\hline $\mathrm{TeO}_{2}$ & $\cdots$ & 0.23 & 0.23 & 0.18 & $\cdots$ \\
\hline $\mathrm{ThO}_{2}$ & 0.16 & $\cdots$ & 0.33 & $\cdots$ & $\cdots$ \\
\hline $\mathrm{UO}_{2}$ & 0.51 & 0.85 & 0.52 & $\cdots$ & $\cdots$ \\
\hline $\mathrm{Y}_{2} \mathrm{O}_{3}$ & 0.20 & 0.19 & 0.20 & $\cdots$ & $\cdots$ \\
\hline $\mathrm{ZnO}$ & 2.52 & 2.50 & 2.50 & 0.21 & 0.21 \\
\hline $\mathrm{ZrO}_{2}$ & 2.63 & 2.61 & 2.65 & 1.71 & 1.66 \\
\hline Total & 99.87 & 100.27 & 99.96 & 100.24 & 98.78 \\
\hline
\end{tabular}

TABLE III. Calculated radioactivities per block at 1.1.1983. Glass JSS-A (total radioactivity: $1.1 \cdot 10^{13} \mathrm{~Bq}$, mass: $1.3 \mathrm{~kg}$ ).

\begin{tabular}{lclc}
\hline \hline $\begin{array}{c}\text { Fission products }(\beta) \\
+{ }^{60} \mathrm{Co}\end{array}$ & $\mathrm{Bq}$ & Actinoids $(\alpha)$ & $\mathrm{Bq}$ \\
& $2.1 \cdot 10^{12}$ & ${ }^{238} \mathrm{Pu}$ & $6.1 \cdot 10^{11}$ \\
${ }^{137} \mathrm{Cs}$ & $3.2 \cdot 10^{11}$ & ${ }^{242} \mathrm{Cm}$ & $5.7 \cdot 10^{10}$ \\
${ }^{134} \mathrm{Cs}$ & $1.9 \cdot 10^{12}$ & ${ }^{243} \mathrm{Cm}+{ }^{244} \mathrm{Cm}$ & $1.2 \cdot 10^{10}$ \\
${ }^{90} \mathrm{Sr}+{ }^{90} \mathrm{Y}$ & $3.8 \cdot 10^{12}$ & ${ }^{241} \mathrm{Am}$ & $1.3 \cdot 10^{11}$ \\
${ }^{106} \mathrm{Ru}+{ }^{106} \mathrm{Rh}$ & $4.3 \cdot 10^{12}$ & ${ }^{239-242} \mathrm{Pu}$ & $8.9 \cdot 10^{9}$ \\
${ }^{144} \mathrm{Ce}+{ }^{144} \mathrm{Pr}$ & $4.8 \cdot 10^{9}$ & & \\
${ }^{60} \mathrm{Co}$ & $5.2 \cdot 10^{10}$ & & \\
${ }^{125} \mathrm{Sb}$ & $2.7 \cdot 10^{10}$ & ${ }^{241} \mathrm{Pu}(\beta)$ & $6.8 \cdot 10^{11}$ \\
\hline
\end{tabular}

A. The long-term rate is a factor of $10^{3}$ lower than the forward rate.

In tests with $\mathrm{MW}$ glass performed at $S / V=$ $1320 \mathrm{~m}^{-1}$, silica saturation was reached rapidly, whereas at $S / V=10 \mathrm{~m}^{-1}$, saturation was not attained. The forward rate was similar to that measured for the COGEMA glass, $k_{+}=1.2 \mathrm{~g} \cdot \mathrm{m}^{-2} \mathrm{~d}^{-1}$, but, in order to reach silica saturation, about ten times more mass of glass had to react. More silica is retained in the surface layer of $\mathrm{MW}$ glass. The estimated long-term rate for MW glass is $0.009 \mathrm{~g} \cdot \mathrm{m}^{-2} \mathrm{~d}^{-1}$, a factor of 5 higher than for the COGEMA glass.

Figure 2 shows the influence of silica concentration in the leachant on the glass corrosion rate ${ }^{4}$ as measured by the concentration of $B$ in the leachate in 28-day corrosion experiments at $90{ }^{\circ} \mathrm{C}$. The normalized elemental mass loss rate, $d N L / d t$, has been plotted as a function of the ion activity product (IAP) of silica. The mass loss rates were obtained from concentration measurements of soluble elements, e.g., Li, Na, Cs, B, Mo, and from experiments with different duration (Table VII). ${ }^{5}$ The decrease of the corrosion rate with increasing silica concentration is evident.

Results from corrosion experiments in flowing water ${ }^{4}$ (flow rate $0.002 \mathrm{~mL} /$ day) are shown in Figs. 3(a) and $3(\mathrm{~b})$, in which boron concentrations have been plotted as a function of time. The trend in the data and the solution concentration are the same for the experiments with nonradioactive [Fig. 3(a)] and radioactive glass [Fig. 3(b)]. The onset of the corrosion reaction was delayed by about 50 days with the radioactive glass. The reason is not known. Otherwise, the solution concentrations were the same in experiments with nonradioactive and radioactive glass. The maximum shows that the solution concentration of boron, as a measure of glass corrosion, is limited by silica transport through the growing surface layer and not by the reaction of the glass with the solution.

Figure 4 shows the effect of bentonite on the corrosion of the radioactive and the nonradioactive glass. ${ }^{4}$ The experimental data are given in Table IV-A. $N L$ values for $\mathrm{B}$ are shown as a function of time at $90^{\circ} \mathrm{C}$. Smaller amounts of bentonite, up to $1 \mathrm{~g}$ in $30 \mathrm{~mL}$ of water, increase the corrosion of glass ABS-118 prior to silica saturation as compared with that in de-ionized water for JSS-A glass [Fig. 1(a), data for $S / V=10 \mathrm{~m}^{-1}$ ]. Higher amounts of bentonite $(4 \mathrm{~g}$ and $40 \mathrm{~g}$ compacted bentonite, respectively, in $30 \mathrm{~mL}$ of water) decrease the extent of glass corrosion as measured for the radioactive glass JSS-A. Amounts of bentonite up to $1 \mathrm{~g}$ increase and larger amounts decrease the $\mathrm{pH}$, relative to the pure glass water system. ${ }^{5,22}$ With increasing $\mathrm{pH}$, the dissociation of orthosilicic acid increases and higher amounts of glass must be dissolved to reach saturation in solution. Thus, the effect of bentonite on glass corro- 


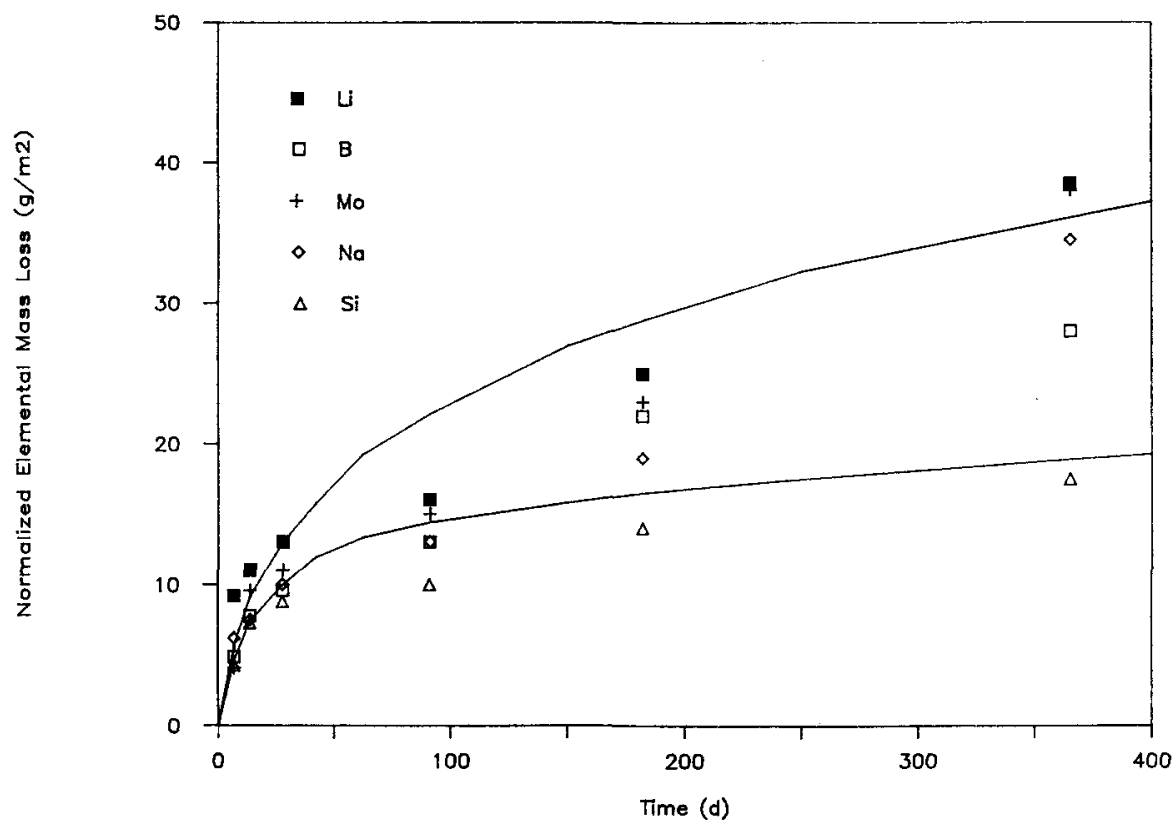

(a)

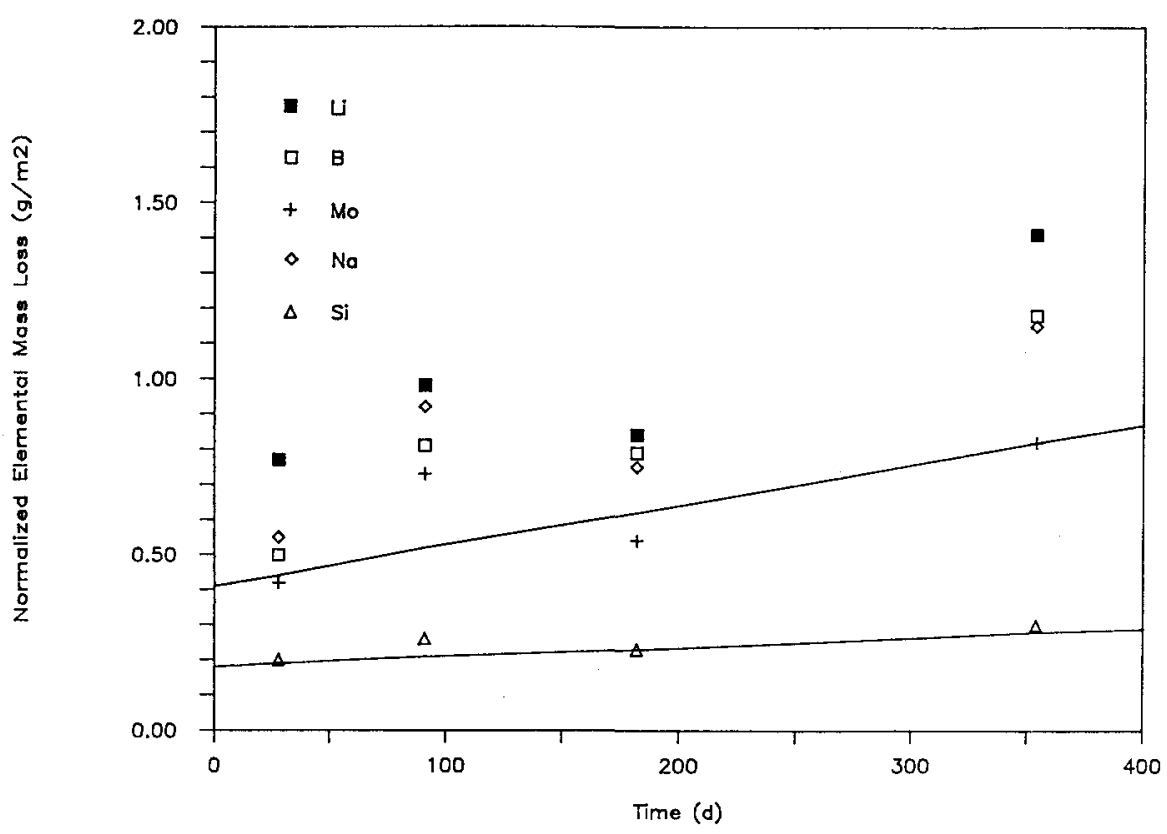

(b)
FIG. 1. (a) Corrosion of glass JSS-A in de-ionized water as a function of time at $90{ }^{\circ} \mathrm{C}, S / V=10 \mathrm{~m}^{-1}$ (glass coupons, static test). Solid lines are calculated. (b) Corrosion of glass JSS-A in deionized water as a function of time at $90^{\circ} \mathrm{C}, S / V=1100 \mathrm{~m}^{-1}$ (glass powder, static test). Solid lines are calculated. sion may be explained by a $\mathrm{pH}$ effect. The long-term glass corrosion rate was not affected by the presence of bentonite. While the normalized concentrations of Cs and B were alike at $S / V=10 \mathrm{~m}^{-1}$ in experiments with glass and water only, normalized Cs concentrations up to 60 times less than those of boron were found when bentonite was present. SIMS depth profiles showed that Cs was missing in the corrosion layer, as were $\mathrm{Li}, \mathrm{Na}$, and B. Therefore, the deficit of $\mathrm{Cs}$ in solution was explained by ion-exchange between $\mathrm{Cs}$ and cations in the bentonite.
Data in Table IV-B and Fig. 5 show the effect of magnetite and of $\mathrm{FeOOH}$ on the corrosion of the glasses. ${ }^{4} N L$ values for Na are shown in Fig. 5 as a function of time. Magnetite and $\mathrm{FeOOH}$ have a deleterious effect on the chemical durability of the glass. The more magnetite present, the greater the extent of glass corrosion prior to silica saturation. The effect of $1 \mathrm{~g}$ of $\mathrm{FeOOH}$ is higher than that of the same amount of magnetite. The chemical effect can be explained with sorption of silica on the surface of the iron corrosion product. Specific surface areas of the different 


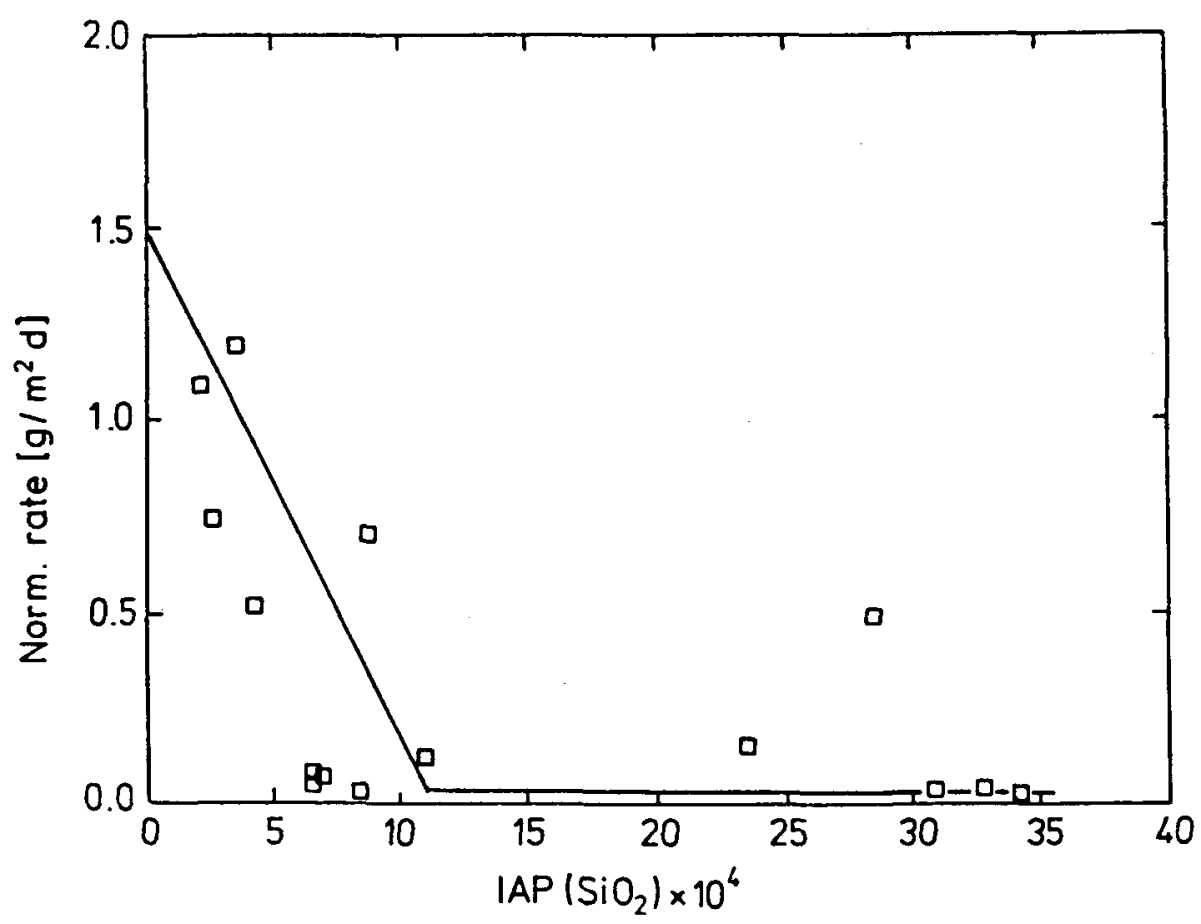

FIG. 2. Dependence of the JSS-A glass corrosion rate on the ion activity product $\mathrm{IAP}_{\mathrm{SiO}_{2}}$ in various leachants $\left(90{ }^{\circ} \mathrm{C}, 28\right.$-day experiments; static test).

iron corrosion products, determined by the BrunnauerEmmett-Teller (BET) method, were $3 \mathrm{~m}^{2} / \mathrm{g}$ and $440 \mathrm{~m}^{2} / \mathrm{g}$ for magnetite and $\mathrm{FeOOH}$, respectively. Silica saturation is reached when all sorption sites are occupied, and the glass continues to corrode at its long-term rate. This rate was by a factor of 5 higher in the presence of magnetite than in de-ionized water. The increase may be explained by continuous slow formation of iron silicate or by multilayer sorption of silica on the surface of the iron corrosion products.

The largest effect of temperature on glass corrosion was noted at the beginning of the experiments, i.e., prior to silica saturation. The activation energies for the forward rates of reaction were $104 \mathrm{~kJ} / \mathrm{mol}$ for JSS-A glass and $82 \mathrm{~kJ} / \mathrm{mol}$ for MW glass. ${ }^{6}$ There was only a minor effect of temperature on glass corrosion in water at $S / V>1000 \mathrm{~m}^{-1}$, i.e., at silica saturation which was attributed to the temperature dependence of silica saturation. In a one-year corrosion experiment, the cumulative release of soluble elements at 50,70 , and $90{ }^{\circ} \mathrm{C}$ varied by less than $20 \%$ when all data were averaged. This was attributed to a small temperature dependence of the silica saturation concentration. A temperature dependence of the long-term rate could not be substantiated. The precision of the experimental data was not high enough to measure variations of less than a factor of two when the rates are in the order of $10^{-3} \mathrm{~g} \cdot \mathrm{m}^{-2} \mathrm{~d}^{-1}$.

There is an effect of glass composition on the extent of corrosion though the differences in the glass compositions are minor for the three glasses R7T7, ABS-118, and JSS-A. The differences are most pronounced before silica saturates in solution. For ABS-118, normalized mass loss values for soluble elements were a factor of two lower than for the radioactive glass and a factor of two higher than for glass R7T7.

The normalized release of actinoids ( $\mathrm{Am}, \mathrm{Pu}$ ) was always less than $1 \%$ of the $\mathrm{B}$ release. The soluble $\mathrm{Pu}$ reached a constant concentration of $10^{-9} \mathrm{~mol} / \mathrm{L}$, independent of the type of experiment. This indicated that the $\mathrm{Pu}$ concentration was controlled by an insoluble $\mathrm{Pu}$ compound, which was not identified. The release of actinoids from the glass was accompanied by colloid formation. For $\mathrm{Pu}$ the concentration of colloidal species was a factor of 2 to 100 higher than that in solution. Colloid formation was not found to be affected by the presence of bentonite and/or magnetite. The total release of $\mathrm{Pu}$ from the glass was higher than the detected sum of dissolved and colloidal species, because some $\mathrm{Pu}$ was absorbed on the container walls.

\section{GLASS CORROSION MECHANISMS}

\section{A. Glass-water reaction}

In the last few years much progress has been made in understanding the reaction mechanism of nuclear waste glasses with aqueous solutions under potential repository conditions (low ground water flow rates, varying temperatures, interaction with waste package components, backfill, and the host rock). Various models have been proposed. ${ }^{13-15}$ However, none of these was advanced enough to be directly applicable for the interpretation of the data compiled in the JSS project. The model developed by Grambow ${ }^{5,12,34}$ was selected and expanded when necessary. Grambow has derived a general rate equation for glass dissolution based on 


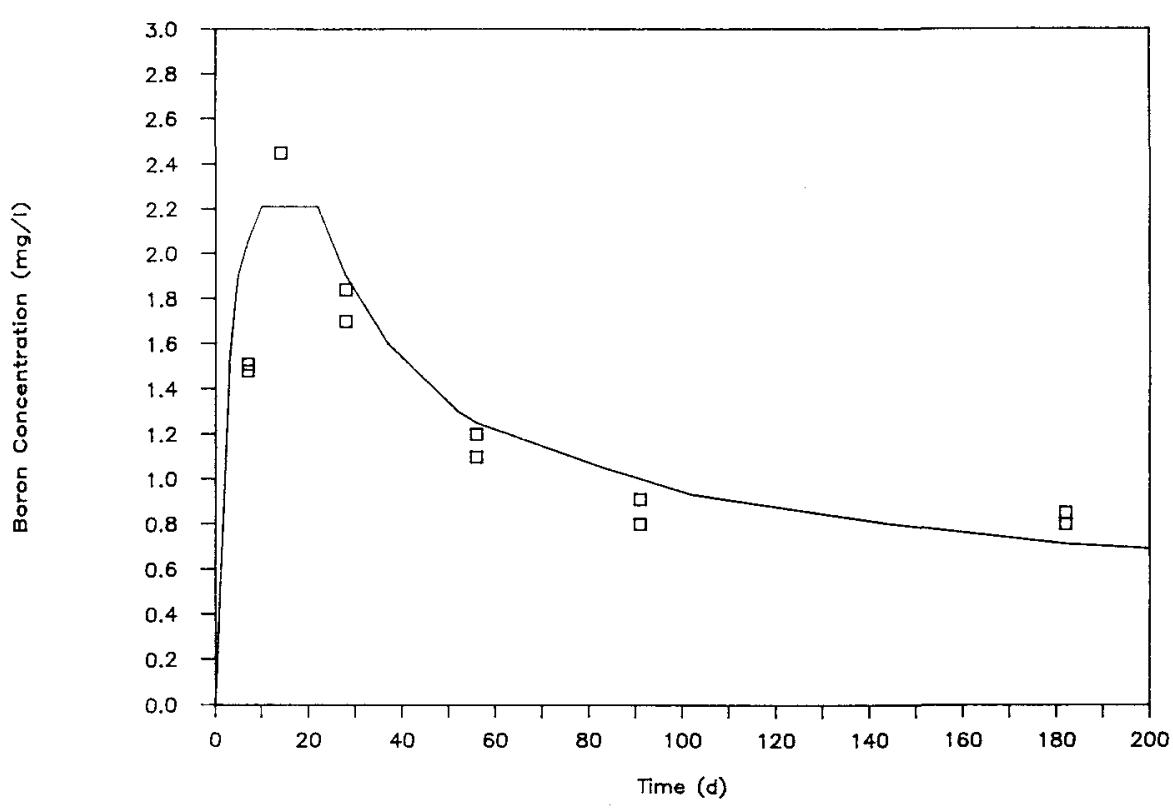

(a)

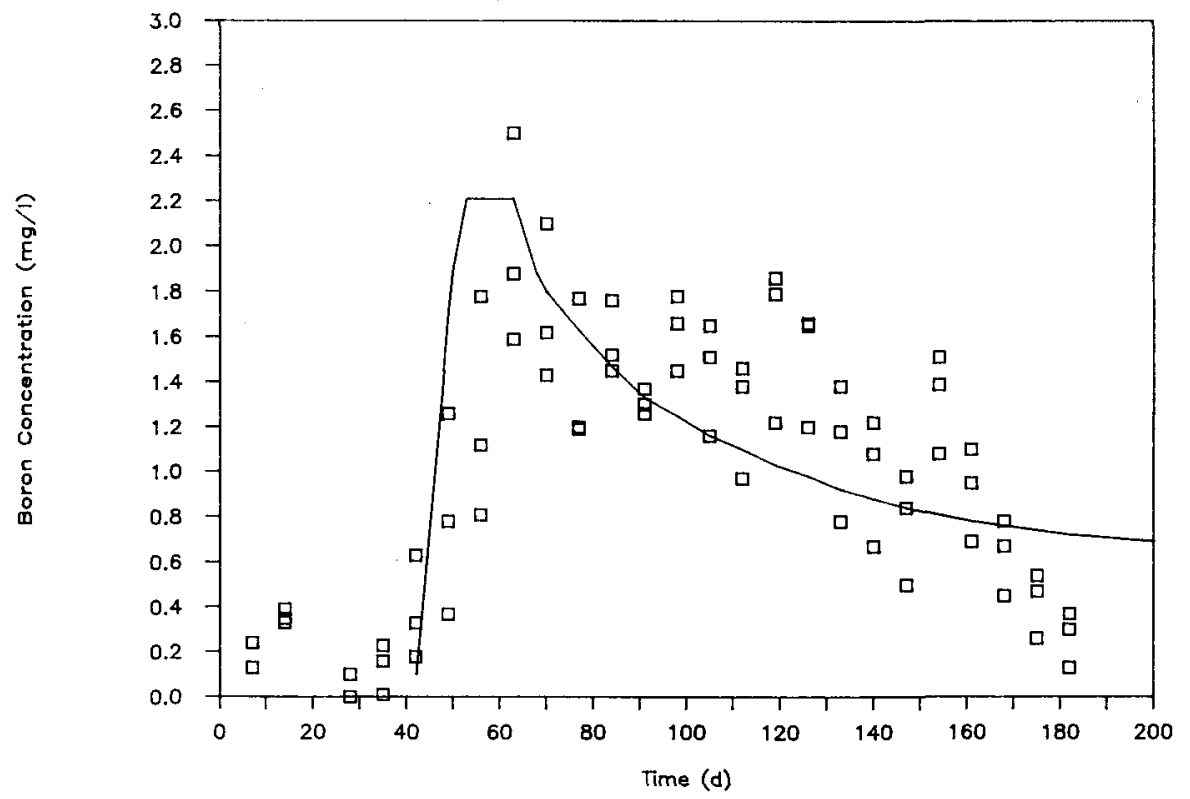

(b)
FIG. 3. Corrosion of borosilicate glass in a flowing solution measured by the release of boron at $90^{\circ} \mathrm{C}$ (DI water, flow rate $0.0002 \mathrm{~mL} / \mathrm{d}, S / V=10 \mathrm{~m}^{-1}$ ). (a) Glass ABS-118 (cell volume $V_{0}=$ $39 \mathrm{~mL}$ ). (b) Glass JSS-A (cell volume $V_{0}=26 \mathrm{~mL}$ ). Solid lines are calculated. work by Aagaard and Helgeson, ${ }^{16}$ who had given a rate equation for the reaction of minerals with aqueous solutions. The derivation of Grambow's rate equation can be found elsewhere., ${ }^{5,12}$ The basic assumption in the formal treatment of the problem is the formation of a surface complex, the decay of which is the irreversible step in the glass network dissolution reaction. The critical reaction product is silicic acid. When this species reacts with silanol groups on the glass surface (a condensation reaction), the glass dissolution rate is lowered. A pHdependent equilibrium between the glass surface (not the bulk glass!) and the silicic acid in solution was as- sumed. A saturation concentration of silica is reached which depends on $\mathrm{pH}$ in the leachate. This equilibrium at the surface does not prevent water from reacting with the pristine glass beneath. A driving force for chemical reactions is maintained, because there is no thermodynamic equilibrium between a glass and an aqueous solution. As a result, glass corrosion continues until the glass phase has disappeared and soluble elements continue to accumulate in solution. A detailed understanding of the long-term glass corrosion reaction is still not available, and this is considered an important field for further research. 


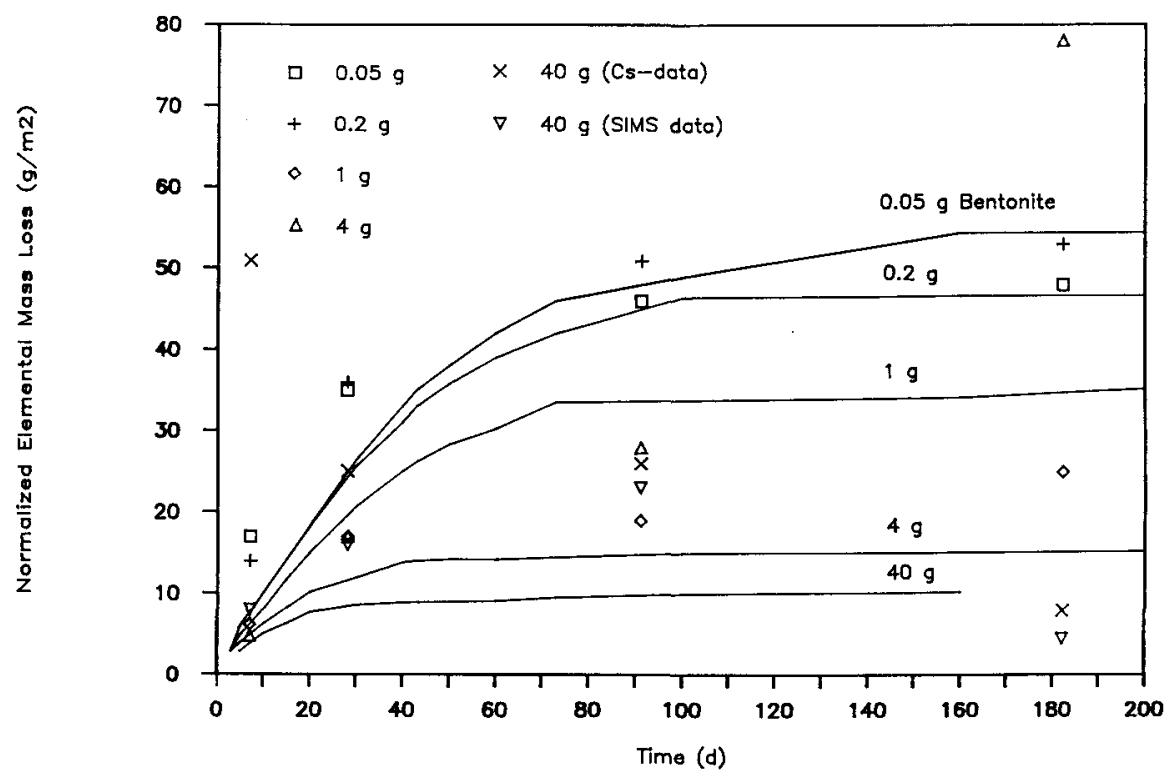

FIG. 4. The effect of bentonite on the corrosion rate of glasses ABS-118 $(0.05 \mathrm{~g}$ to $1 \mathrm{~g}$ of bentonite) and JSS-A ( $4 \mathrm{~g}$ and $40 \mathrm{~g}$ of compacted bentonite) measured by the release of boron at $90{ }^{\circ} \mathrm{C}$. Solid lines are calculated.

In its shortest form, Grambow's rate equation is given as

$$
r_{m}=k_{+} \cdot\left(1-a_{\mathrm{Si}} / a_{\mathrm{sat}}\right)
$$

where $r_{m}$ is the corrosion rate, i.e., the rate of dissolution of the glass network, $k_{+}$is the 'forward rate' of reaction, $a_{\mathrm{Si}}$ is the activity of orthosilicic acid in solution, and $a_{\text {sat }}$ is the corresponding activity at saturation. A plot of corrosion rates as a function of silica in solution (Fig. 2) can be used to determine the constants $k_{+}$and $a_{\text {sat }}$ in Eq. (1), provided that hydrolysis of orthosilic acid is small.

If transport of silica through the surface layer, rather than the glass-water reaction, determines the corrosion rate, Eq. (2) can be used instead of Eq. (1):

$$
r_{t}=D / L\left(a_{\mathrm{Si}, s}-a_{\mathrm{Si}}\right)+r_{\infty}
$$

$r_{t}$ is the rate of transport per unit of surface area, $D$ is a diffusion coefficient, $L$ the thickness of the transport barrier (e.g., a surface layer), and $a_{\mathrm{Si}, s}$ and $a_{\mathrm{Si}}$ designate the activities of orthosilicic acid at the glass surface and in the bulk solution, respectively. The last term, $r_{\infty}$, prevents the rate of transport from becoming zero in order to match experimental results. The glass corrosion reaction does not cease at silica saturation, ${ }^{6,17,18}$ and transport of silica must continue even without a concentration gradient in the surface layer. Under this condition, transport is identical with the mass transfer of silica from the glass phase to a solid alteration product: $r_{t}=r_{\infty}$. For $r_{t}=r_{m}$, Eqs. (1), with $a_{\mathrm{Si}}=a_{\mathrm{Si}, s}$, and (2) can be solved for $a_{\mathrm{Si}, s}$, and this expression can be introduced in Eq. (1) to obtain Eq. (3):

$$
\begin{array}{r}
r_{m}=k_{+} \cdot\left[\left(D / L\left(a_{\mathrm{sat}}-a_{\mathrm{Si}}\right)+r_{\infty}\right) /\right. \\
\left.\left(D \cdot a_{\mathrm{sat}} / L+k_{+}\right)\right] .
\end{array}
$$

The effect of a flowing solution on glass corrosion has been taken into account by Eq. (4):

$$
d C_{g} / d t=S / V \cdot r_{m}-F / V \cdot C_{g}
$$

where $C_{g}$ designates the apparent concentration of glass in the leachate (grams of 'glass' dissolved). $F$ is the flow rate.

The variable $a_{\mathrm{Si}}$ in the bulk solution may be a complicated function of chemical reactions which consume silicon, e.g., precipitation of reaction products, particularly in a closed system. The chemical reactions in solution depend on the reaction progress, i.e., the amount

\begin{tabular}{|c|c|c|c|c|c|c|}
\hline \multirow{2}{*}{$\begin{array}{c}\text { Contact } \\
\text { time, } \\
\text { days }\end{array}$} & \multicolumn{3}{|c|}{ Glass ABS-118 } & \multicolumn{3}{|c|}{ Glass JSS-A } \\
\hline & $0.05 \mathrm{~g}$ & $0.2 \mathrm{~g}$ & $1 \mathrm{~g}$ & $4 \mathrm{~g}$ & $\begin{array}{c}40 \mathrm{~g} \\
\text { Cs data }\end{array}$ & $\begin{array}{c}40 \mathrm{~g} \\
\text { SIMS data }\end{array}$ \\
\hline 7 & 17 & 14 & 6.2 & 4.8 & 51 & 8 \\
\hline 28 & 35 & 36 & 17 & 17 & 25 & 16 \\
\hline 91 & 46 & 51 & 19 & 28 & 26 & 23 \\
\hline 182 & 48 & 53 & 25 & 78 & 8 & 4.5 \\
\hline
\end{tabular}
of glass dissolved per unit of solution volume, and on glass and initial solution composition. Only in the absence of secondary chemical reactions of silica and at a

TABLE IV-A. Effect of bentonite on glass corrosion. Normalized boron mass losses $\left(\mathrm{g} / \mathrm{m}^{2}\right)$. 
TABLE IV-B. Effect of canister corrosion products on the normalized elemental mass losses.

\begin{tabular}{|c|c|c|c|c|c|c|c|c|}
\hline \multirow[b]{2}{*}{$\begin{array}{l}\text { Reaction } \\
\text { time (d) }\end{array}$} & \multicolumn{8}{|c|}{ Normalized elemental mass loss $\left(\mathrm{g} / \mathrm{m}^{2}\right)$} \\
\hline & $\mathrm{B}^{\mathrm{a}}$ & $\mathrm{Mo}^{\mathrm{b}}$ & $\mathrm{Na}^{\mathrm{b}}$ & $\mathrm{Al}^{\mathrm{b}}$ & $\mathrm{Ca}^{\mathrm{b}}$ & $\mathrm{Sr}^{\mathrm{b}}$ & $\mathrm{Cs}^{\mathrm{b}}$ & $\mathbf{P u}^{\mathrm{b}}$ \\
\hline \multicolumn{9}{|c|}{ JSS-A glass $+1 \mathrm{~g}$ magnetite } \\
\hline 7 & 16 & 6 & & 2 & 8 & 12 & 7 & 1 \\
\hline 28 & 17 & 11 & 11 & 11 & 8 & 15 & 16 & 2 \\
\hline 91 & 33 & 47 & & 5 & 11 & 23 & 33 & 1 \\
\hline 182 & 71 & 98 & 75 & 17 & 8 & 16 & 43 & \\
\hline \multicolumn{9}{|c|}{ ABS-118 glass $+1 \mathrm{~g}$ magnetite } \\
\hline 7 & 2 & 3 & 5 & $<\mathrm{DL}$ & 8 & 5 & & \\
\hline 28 & 28 & 48 & 31 & 26 & 22 & 24 & & \\
\hline 91 & 58 & 83 & 67 & 47 & 54 & 54 & & \\
\hline 182 & 70 & 38 & 82 & 58 & 69 & 64 & & \\
\hline 365 & 96 & 66 & 101 & 69 & 99 & 84 & & \\
\hline 547 & 106 & 52 & 114 & 58 & 112 & 91 & & \\
\hline \multicolumn{9}{|c|}{ ABS- 118 glass $+0.1 \mathrm{~g}$ magnetite } \\
\hline 7 & 2 & 5 & 4 & $<\mathrm{DL}$ & 1 & 1 & & \\
\hline 28 & 10 & 16 & 13 & 8 & 7 & 9 & & \\
\hline 91 & 12 & 15 & 11 & 4 & 3 & 6 & & \\
\hline 182 & 17 & 25 & 17 & 9 & 6 & 8 & & \\
\hline 365 & 36 & 59 & 33 & 5 & 9 & 7 & & \\
\hline 547 & 39 & 43 & 40 & 12 & 12 & 10 & & \\
\hline \multicolumn{9}{|c|}{$\underline{\text { ABS- } 118 \text { glass }+1 \mathrm{~g} \mathrm{FeOOH}}$} \\
\hline 7 & c & 10 & c & c & 14 & 9 & & \\
\hline 28 & 39 & 118 & 18 & 60 & 22 & 32 & & \\
\hline 91 & 26 & 182 & 58 & 43 & 46 & 49 & & \\
\hline 182 & 35 & 138 & 99 & 88 & 89 & 94 & & \\
\hline 365 & 83 & 393 & 228 & 201 & 243 & 159 & & \\
\hline 547 & 141 & 338 & 286 & 243 & 268 & 214 & & \\
\hline
\end{tabular}

$\mathrm{DL}=$ detection limit

$\mathrm{a}=$ based on solution analysis only

$\mathrm{b}=$ based on analyses of solution and corrosion product

c $=$ lower than blank

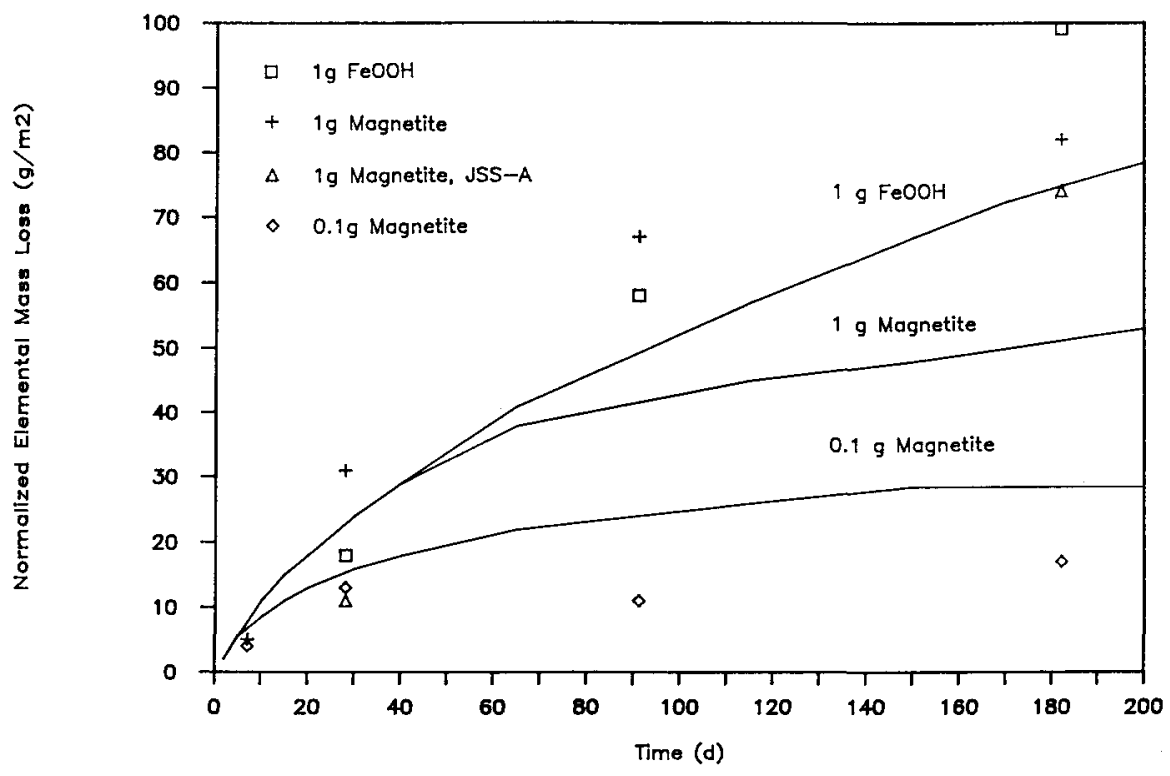

FIG. 5. Effect of magnetite on the corrosion of glasses ABS-118 and JSS-A measured by the release of sodium at $90^{\circ} \mathrm{C}$. Solid lines are calculated. 
constant $\mathrm{pH}$ can the time dependence of $a_{\mathrm{Si}}$ be calculated by integrating Eq. (1). Potential chemical reactions in the leachate were calculated with the help of the computer code PHREEQE, ${ }^{19}$ and the results were evaluated by comparing calculated equilibrium solution concentrations and the measured values for a variety of elements, including Si (see Sec. V).

\section{B. Bentonite/glass/water- and iron corrosion product/glass/water-reactions}

Effects of waste package components on the corrosion of nuclear waste borosilicate glass can be taken into account quantitatively when the chemical interactions are known. In the JSS project, bentonite and magnetite (and in a few cases $\mathrm{FeOOH}$ ) were studied. The bentonite and the iron corrosion products were considered separately in the theoretical treatment. Effects of bentonite on the chemical durability of the glass were accounted for by a description of bentonite/water interactions. In this regard, montmorillonite is the most important component. The composition of the montmorillonite under study was ${ }^{5}$ :

$$
\mathrm{Na}_{0.3}\left(\mathrm{Si}_{3.96} \mathrm{Al}_{0.04}\right)\left(\mathrm{Al}_{1.55} \mathrm{Fe}^{3+}{ }_{0.2} \mathrm{Fe}^{2+}{ }_{0.1} \mathrm{Mg}_{0.24}\right) \mathrm{O}_{10}(\mathrm{OH})_{2} \text {. }
$$

The solubility of the mineral and ion-exchange equilibria with $\mathrm{H}^{+}, \mathrm{Na}^{+}, \mathrm{K}^{+}, \mathrm{Cs}^{+}, \mathrm{Ca}^{2+}$, and $\mathrm{Mg}^{2+}$ were considered. $\mathrm{H}^{+}$is important ${ }^{20}$ because a significant fraction of exchangeable cations is $\mathrm{H}^{+}$. If $\mathrm{H}^{+}$is neglected as an exchangeable cation, the calculated $\mathrm{pH}$ increases ${ }^{21}$ during the glass corrosion, whereas $\mathrm{pH}$ decreases ${ }^{22}$ in the experiment. Ion-exchange was described by the ionexchange equilibrium

$$
\mathbf{K}=a_{M Z_{n}} /\left(a_{Z}^{n} \cdot a_{M}\right)
$$

where $a_{M Z_{n}}$ and $a_{Z}$ are the activities of occupied and unoccupied sites and $a_{M}$ is the activity of the cation $M$ in solution. Average exchange constants were calculated from cation exchange capacities and from solution concentrations of exchangeable cations $\left(\log \mathbf{K}_{\mathrm{Na}}=2.92\right.$, $\log \mathbf{K}_{\mathrm{K}}=2.89, \log \mathbf{K}_{\mathrm{Cs}}=3.8, \log \mathbf{K}_{\mathrm{Ca}}=6.93$, $\left.\log \mathbf{K}_{\mathrm{Mg}}=6.71\right) .^{5}$ The reaction with $\mathrm{H}^{+}$was described by the $p \mathbf{K}$ value for the hydrolysis of silicic acid $\left(\log \mathbf{K}_{\mathrm{H}}=9.9\right)$. This approximation is supported by the measured $p \mathbf{K}$ of 9.4 for the hydroxilated silica constituents of bentonite. Minor constituents of the bentonite such as quartz, felspar, and siderite were treated as inert materials. For $90{ }^{\circ} \mathrm{C}$, equilibrium between calcite, also a minor constituent of bentonite, and water was assumed and precipitation of the potential bentonite alteration products ferrihydrite and gibbsite considered. ${ }^{5}$ In order to account for the high concentrations of $\mathrm{Cl}^{-}$and $\mathrm{SO}_{4}{ }^{2-}$ detected in solution, it was assumed that these impurities of bentonite are dissolved instantaneously and quantitatively. Equilibrium with atmospheric $\mathrm{CO}_{2}$ was assumed when access of air could not be excluded during the corrosion experiment.

Various experiments ${ }^{23,24}$ have shown that iron corrosion products enhance the glass corrosion rate. The exact mechanism of interaction between these products and the glass corrosion process is not known. However, the assumption that silica in solution is consumed by reactions with iron corrosion products is compatible with the observed enhancement of the glass corrosion rate. For a quantitative treatment, silica sorption on the surface of the magnetite is assumed. The reaction is described by the formation of a hypothetical, neutral iron-silica solution complex 'Si-sorb' from a neutral sorption site 'sorb':

$$
K=a_{\mathrm{Si} \text {-sorb }} /\left(a_{\mathrm{SiO}_{2}} \cdot a_{\text {sorb }}\right)
$$

assuming a high stability constant (e.g., $\log \mathbf{K}=10$ ). ${ }^{5}$ This equation allows one to consider the available surface sites in the mass balance of a reaction path model. The number of sorption sites (in units of a concentration) can be calculated from the specific surface area and the total mass of iron corrosion products present. ${ }^{5}$

\section{GLASS CORROSION RATES}

\section{A. Borosilicate nuclear waste glasses}

The mass transfer from the glass phase into solution can be described by a reaction path model. ${ }^{5}$ The reaction path, i.e., the sequence of chemical reactions in solution as a function of the amount of glass dissolved, was modeled with the help of the geochemical code PHREEOE ${ }^{19}$ and the results combined with a code to calculate rates. The combined code, GLASSOL, is published in a JSS report where more details, justifications, and results can be found than in the following short description. ${ }^{5}$ The connection between GLASSOL and PHREEOE is shown in Fig. 6. In a first step, Si concentrations in the leachate are calculated as a function of reaction progress based on selected potential reaction products (Table V). Some phases listed in Table V have no effect on the concentration of $\mathrm{Si}$ in solution. However, the inclusion of these phases into the calculation increases the confidence in the reaction path selected, because the other calculated elemental concentrations can be compared with the analytical results. In a second step, the calculated $\mathrm{Si}$ concentrations are used in Eq. (4) [and Eq. (5) in a flow experiment] to calculate corrosion rates. In Table VI, the data listed are used in the calculation of corrosion rates for MW glass. ${ }^{6}$ Respective values for JSS-A glass have been included in Table VIII. The constants in Eq. (4), $k_{+}, a_{\text {sat }}$, and $r_{\infty}$, have been determined experimentally. The diffusion coefficient of the surface layer (see Table VI) was determined from a best fit of the calculated corrosion curve to the data in Figs. 3(a) and 3(b). $L$, the thickness of the surface layer on the corroded glass in Eq. (2), depends 


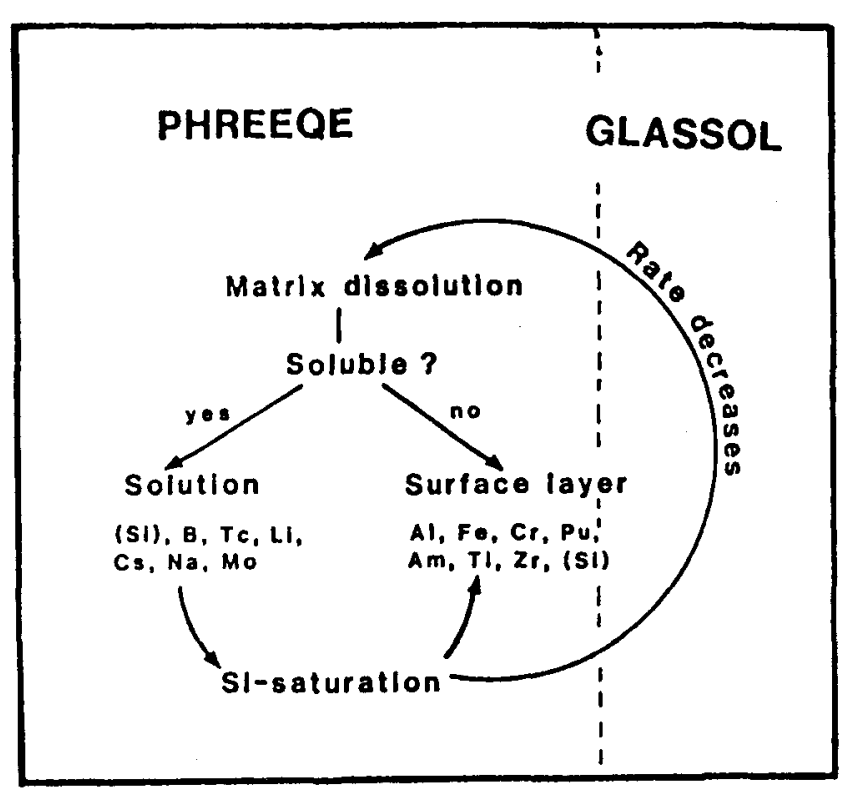

FIG. 6. Illustration of the combination of solubility based reaction path calculations for the dissolution of glass with kinetic constraints.

on reaction progress. The layer thickness is assumed to be proportional to the amount of glass corroded and is calculated from the concentration of boron in solution. The degree of silica sorption (Table VI) accounts for the retention of silica on the glass surface. In GLASSOL,

TABLE V. List of potential glass alteration products.

\begin{tabular}{|c|c|c|}
\hline Elements & Minerals & Formulae \\
\hline $\mathrm{B}, \mathrm{Li}, \mathrm{Cs}$ & None & \\
\hline $\mathrm{Na}$ & Analcime & $\mathrm{NaAlSi}_{2} \mathrm{O}_{6} \cdot \mathrm{H}_{2} \mathrm{O}$ \\
\hline $\mathrm{Si}$ & & $\mathrm{SiO}_{2}(\log K=-2.94)$ \\
\hline \multirow[t]{2}{*}{$\mathrm{Al}$} & Gibbsite & $\mathrm{Al}(\mathrm{OH})_{3}$ \\
\hline & $\begin{array}{l}\text { Analcime } \\
\text { Na-montmorillonite }\end{array}$ & $\begin{array}{l}\mathrm{Na}_{0.29} \mathrm{Ca}_{0.11} \mathrm{Si}_{3.94} \mathrm{Al}_{1.58^{-}} \\
\quad \mathrm{Mg}_{0.22} \mathrm{Fe}_{0.19}^{\mathrm{III}} \mathrm{O}_{10}(\mathrm{OH})_{2}\end{array}$ \\
\hline $\mathrm{Fe}$ & Ferrihydrite & $\mathrm{Fe}(\mathrm{OH})_{3}$ \\
\hline Mo & $\cdots$ & $\mathrm{BaMoO}_{4}, \mathrm{CaMoO}_{4}$ \\
\hline $\mathrm{Nd}$ & $\cdots$ & $\mathrm{Nd}(\mathrm{OH})_{3}$ \\
\hline $\mathrm{Ca}$ & Calcite & $\begin{array}{l}\mathrm{CaCO}_{3} \\
\mathrm{CSH}(\mathrm{I})=\mathrm{CaSiO}_{3} \cdot \mathrm{H}_{2} \mathrm{O}\end{array}$ \\
\hline $\mathrm{Zn}$ & $\begin{array}{l}\text { Ca-montmorillonite } \\
\text { Zn-chamosite }\end{array}$ & $\begin{array}{l}\mathrm{Ca}_{0.17} \mathrm{Si}_{3.67} \mathrm{Al}_{2.33} \mathrm{O}_{10}(\mathrm{OH})_{2} \\
\left(\mathrm{Si}_{1.55} \mathrm{Al}_{0.32}\right)\left(\mathrm{Al}_{1.06} \mathrm{Zn}_{1.81}\right) \\
\quad \mathrm{O}_{5}(\mathrm{OH})_{4}\end{array}$ \\
\hline \multirow[t]{2}{*}{$\mathrm{Sr}$} & Strontianite & $\mathrm{SrCO}_{3}$ \\
\hline & Celestite & $\mathrm{SrSO}_{4}$ \\
\hline $\mathrm{Mn}$ & $\begin{array}{l}\text { Rhodochrosite } \\
\text { Pyrolusite }\end{array}$ & $\begin{array}{l}\mathrm{MnCO}_{3} \\
\beta-\mathrm{MnO}_{2}\end{array}$ \\
\hline $\mathbf{P}$ & $\begin{array}{l}\text { Hydroxyapatite } \\
\text { Strengite } \\
\text { Vivianite }\end{array}$ & $\begin{array}{l}\mathrm{Ca}_{5}\left(\mathrm{PO}_{4}\right)_{3} \mathrm{OH} \\
\mathrm{FePO} \mathrm{PO}_{4} \cdot 2 \mathrm{H}_{2} \mathrm{O} \\
\mathrm{Fe}\left(\mathrm{PO}_{4}\right)_{2} \cdot 8 \mathrm{H}_{2} \mathrm{O}\end{array}$ \\
\hline Mg & $\begin{array}{l}\text { Sepiolite } \\
\text { Brucite } \\
\text { Artinite }\end{array}$ & $\begin{array}{l}\mathrm{Mg}_{2} \mathrm{Si}_{3} \mathrm{O}_{6}(\mathrm{OH})_{4} \\
\mathrm{Mg}(\mathrm{OH})_{2} \\
\mathrm{MgCO}_{3}\end{array}$ \\
\hline $\mathrm{Ba}$ & Barite & $\mathrm{BaSO}_{4}$ \\
\hline $\mathrm{U}$ & Schoepite & $\mathrm{UO}_{2}(\mathrm{OH})_{2} \cdot \mathrm{H}_{2} \mathrm{O}$ \\
\hline $\mathrm{Zr}$ & Zircon & $\mathrm{ZrSiO}_{4}$ \\
\hline
\end{tabular}

TABLE VI. Rate and stability constants and other parameters for MW glass.

\begin{tabular}{ll}
\hline \hline Forward rate $k_{+}\left(\mathrm{g} \cdot \mathrm{m}^{-2} \mathrm{~d}^{-1}\right)$ & 1.2 \\
Activation energy for $k_{+}(\mathrm{kJ} / \mathrm{mol})$ & 82 \\
Long-term rate $\left(\mathrm{g} \cdot \mathrm{m}^{-2} \mathrm{~d}^{-1}\right)$ & 0.009 \\
Saturation constant for $\mathrm{SiO}_{2} \log K$, at $90{ }^{\circ} \mathrm{C}$ & -2.81 \\
$\mathrm{SiO}_{2}$ diffusion coefficient $\left(\mathrm{m}^{2} / \mathrm{d}\right)$ & $5 \cdot 10^{-7}$ \\
Degree of silica sorption in the surface layer $(\%)$ & 35 \\
\hline
\end{tabular}

the saturation concentration of silicic acid was replaced by a stability constant, $\mathbf{K}_{\mathrm{SiO}_{2}}$, for the reaction $\mathrm{SiO}_{2}+$ $2 \mathrm{H}_{2} \mathrm{O}=\mathrm{H}_{4} \mathrm{SiO}_{4}\left(\mathrm{~K}_{\mathrm{SiO}_{2}}=a_{\text {sat }}\right.$ for $\left.a_{\mathrm{H}_{2} \mathrm{O}}=1\right)$.

The results of the calculations with GLASSOL are shown as solid curves together with the experimental results in Figs. 1, 3(a), 3(b), 4, and 5. A comparison between experimental data and calculations reveals:

(1) The model provides a qualitatively correct description of the glass corrosion process.

(2) An overall evaluation of the agreement between modeled results and experimental data shows that predicted values do not generally deviate from the measurements by more than $30 \%$ for soluble elements, i.e., those elements which did not form solid reaction products in the course of the experiment.

(3) For insoluble elements, i.e., elements which did form solid reaction products, the discrepancies are higher than $30 \%$, in several cases up to a factor of two. The main uncertainty in the model calculations lies in the proper selection of the precipitating phases, their chemical composition, and in the respective solubility constants.

The degree of agreement between GLASSOL calculations and experimental results was considered as a validation of the glass corrosion model including interactions with iron corrosion products and bentonite for time periods up to one year. An extrapolation of corrosion rates over time periods of interest for radioactive waste disposal cannot be substantiated by corrosion experiments in the laboratory alone. Therefore, validation of a long-term corrosion rate and its use in the model was accomplished by investigation of corrosion phenomena of natural basalt glasses of great age.

\section{B. Natural glasses}

Basalt glasses have been recognized as natural analogues for HLW glasses, and their study has provided important information on the glass water reaction over geologic periods of time. ${ }^{25-27,35} \mathrm{~A}$ data base on alteration phenomena of basaltic glasses has been generated within the JSS project. Information extracted from these data includes (1) the effect of flow rate and silica saturation on reaction progress and rates; (2) effect of temperature on corrosion rate $^{28}$; (3) variation of rind thicknesses with age; (4) the degree of alteration as a function of surface area; (5) the identification and 


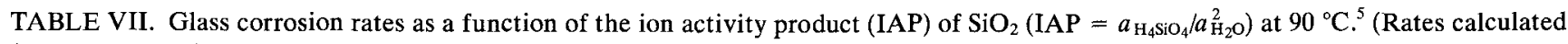
from concentration measurements of soluble elements.)

\begin{tabular}{|c|c|c|c|}
\hline Experiment & $\mathrm{IAP} \cdot 10^{4}$ & $\begin{array}{c}\text { Rate } \\
\mathrm{g} \cdot \mathrm{m}^{-2} \mathrm{~d}^{-1}\end{array}$ & Elements \\
\hline Glass JSS-A, de-ionized water, $S / V=10 \mathrm{~m}^{-1}, 3$-day & 2.21 & 1.1 & $\mathrm{Li}, \mathrm{Na}, \mathrm{Cs}, \mathrm{B}, \mathrm{Mo}$ \\
\hline Glass R7T7, de-ionized water, $S / V=50 \mathrm{~m}^{-1}, 1$ day & 2.72 & 0.75 & $\mathrm{~B}, \mathrm{Li}$ \\
\hline Glass JSS-A, de-ionized water, $S / V=10 \mathrm{~m}^{-1}, 7$-day & 3.59 & 1.2 & $\mathrm{Li}, \mathrm{Na}, \mathrm{Cs}, \mathrm{B}, \mathrm{Mo}$ \\
\hline Glass JSS-A, Allard water, $S / V=10 \mathrm{~m}^{-1}, 7$-day & 4.31 & 0.52 & $\mathrm{Li}, \mathrm{Na}, \mathrm{Cs}, \mathrm{B}, \mathrm{Mo}, \mathrm{Sr}$ \\
\hline Glass JSS-A, de-ionized water, $S / V=10 \mathrm{~m}^{-1}, 91$-day & 6.53 & 0.07 & $\mathrm{Li}, \mathrm{Na}, \mathrm{Cs}, \mathrm{B}, \mathrm{Mo}$ \\
\hline Glass JSS-A, Allard water, $S / V=10 \mathrm{~m}^{-1}, 91$-day & 6.53 & 0.085 & $\mathrm{Li}, \mathrm{Na}, \mathrm{Cs}, \mathrm{B}, \mathrm{Mo}, \mathrm{Sr}$ \\
\hline Glass JSS-A, de-ionized water, $S / V=10 \mathrm{~m}^{-1}, 182$-day & 6.99 & 0.075 & $\mathrm{Li}, \mathrm{Na}, \mathrm{Cs}, \mathrm{B}, \mathrm{Mo}$ \\
\hline Glass R7T7, de-ionized water, $S / V=50 \mathrm{~m}^{-1}$, 364-day & 8.41 & 0.033 & $\mathrm{~B}, \mathrm{Li}$ \\
\hline Glass JSS-A, silicate water, $S / V=10 \mathrm{~m}^{-1}, 3$-day & 8.61 & 0.7 & $\mathrm{Li}, \mathrm{Cs}, \mathrm{B}, \mathrm{Mo}$ \\
\hline Glass JSS-A, silicate water, $S / V=10 \mathrm{~m}^{-1}, 182$-day & 11.1 & 0.13 & $\mathrm{Li}, \mathrm{Cs}, \mathrm{B}, \mathrm{Mo}$ \\
\hline Glass JSS-A, silicate water + granite, $S / V=10 \mathrm{~m}^{-1}, 3$-day & 23.3 & 0.17 & $\mathrm{Li}, \mathrm{Cs}, \mathrm{B}$ \\
\hline Glass JSS-A, silicate water + granite, $S / V=300 \mathrm{~m}^{-1}, 3$-day & 28.5 & 0.48 & $\mathrm{Li}, \mathrm{Cs}, \mathrm{B}, \mathrm{Sr}$ \\
\hline Glass JSS-A, de-ionized water + granite, $S / V=300 \mathrm{~m}^{-1}$, 28-day & 30.9 & 0.04 & $\mathrm{Li}, \mathrm{Cs}$ \\
\hline Glass JSS-A, silicate water + granite, $S / V=300 \mathrm{~m}^{-1}, 182$-day & 32.7 & 0.01 & $\mathrm{Li}, \mathrm{Cs}, \mathrm{B}, \mathrm{Sr}$ \\
\hline Glass JSS-A, de-ionized water + granite, $S / V=10 \mathrm{~m}^{-1}, 28$-day & 34.2 & 0.03 & Depletion depth ${ }^{\mathrm{a}}$ \\
\hline
\end{tabular}

${ }^{\text {a}}$ Determined by the SIMS technique.

composition of phases that form during the corrosion process. The effect of solution residence time and silica saturation was determined by comparing alteration features observed on dredged samples from the open ocean floor with those of samples recovered from drill cores beneath the sediment cover. In the case of dredged samples, silica saturation was not reached in the surrounding seawater, and the glass corroded faster than in a more confined environment. Only those sam- ples for which an independent age determination could be found in the literature were studied.

In general, reaction rates derived from rind thickness and the age of samples from the open ocean floor (dredged samples) are reported to be in the order of 3-20 $\mu \mathrm{m}$ per thousand years, whereas rates derived from alteration rinds on drill core samples are typically two to three orders of magnitude lower, $0.01-0.1 \mu \mathrm{m} /$ $1000 \mathrm{yr}$, at 0 to $3{ }^{\circ} \mathrm{C}$. This is attributed to differences in

TABLE VIII. Parameters and data used in the performance analysis of COGEMA borosilicate glass.

\begin{tabular}{|c|c|c|}
\hline & Values & Units \\
\hline \multicolumn{3}{|l|}{ 1. Materials properties (this work) } \\
\hline Forward rate & 1.5 & $g \cdot m^{-2} d^{-1}$ \\
\hline Long-term rate & 0.0025 & $g \cdot m^{-2} d^{-1}$ \\
\hline Activation energy for the forward rate & 104 & $\mathrm{~kJ} / \mathrm{mol}$ \\
\hline $\log K$ for silica saturation & -2.94 & \\
\hline Diffusion coefficient of $\mathrm{SiO}_{2}$ & $10^{-8}$ & $\mathrm{~m}^{2} / \mathrm{d}$ \\
\hline $\begin{array}{l}\text { Selection of glass alteration phases for reaction } \\
\text { path modeling; see Table V }\end{array}$ & $\cdots$ & $\cdots$ \\
\hline Degree of silica sorption in the surface layer & 20 & Percent \\
\hline \multicolumn{3}{|l|}{ 2. Production-related waste form data (after COGEMA) } \\
\hline Glass block geometric surface area & 1.71 & $\mathrm{~m}^{2}$ \\
\hline Factor for surface area increase (cracks) & 10 & \\
\hline Canister filling height & 1.08 & m \\
\hline Glass block diameter & 0.42 & m \\
\hline Glass density & $2.75 \cdot 10^{3}$ & $\mathrm{~kg} / \mathrm{m}^{3}$ \\
\hline Total mass of glass & 412.5 & $\mathrm{~kg}$ \\
\hline Molecular mass of the glass & 61 & $\mathrm{~g} / \mathrm{mol}$ \\
\hline Void volume of the container & 0.02 & $\mathrm{~m}^{3}$ \\
\hline \multicolumn{3}{|l|}{ 3. Hypothetical repository conditions } \\
\hline $\begin{array}{l}\text { Groundwater flow rate; varied for sensitivity } \\
\text { studies between }\end{array}$ & $\begin{array}{l}0-10^{-5} \\
(0-100\end{array}$ & $\begin{array}{l}\mathbf{m}^{3} / \mathbf{h} \\
\mathrm{L} / \mathrm{yr})\end{array}$ \\
\hline Glass surface area to solution volume ratio $(S / V)$ & 853 & $\mathrm{~m}^{-1}$ \\
\hline
\end{tabular}


the silica concentration of the surrounding solution: $0.4-4 \mathrm{mg} / \mathrm{L} \mathrm{SiO} 2$ in the former case and $\mathrm{SiO}_{2}$ saturation in the latter. The results of the glass samples studied are plotted in Fig. $7^{29}$ according to their rind thicknesses and corrosion conditions. As can be seen, there are two distinct ranges of rind thickness/age relationships. In terms of Grambow's corrosion model, samples can be identified which were corroded at the forward rate of reaction in a solution unsaturated with respect to silica, and samples which were corroded at the longterm rate in a silica-saturated environment. Taking the uncertainties of the geologic record (age determination and time of contact with water) into account, a constant long-term rate may be assumed in a first approximation. There are samples which fall off the straight line drawn for the long-term rate (toward higher apparent ages), but the geology of specific localities suggested that the samples had been sealed by authigenic cements, thus preventing further contact with water.

Apart from rind thickness measurements on altered basalt glasses, a petrographic characterization was completed and analytical electron microscopy (AEM) applied to identify alteration products and concentration changes in the altered layers. ${ }^{7}$ In terms of absolute elemental concentrations, $\mathrm{SiO}_{2}, \mathrm{MgO}$, and $\mathrm{CaO}$ are nearly always depleted in the altered layer relative to the glass. $\mathrm{FeO}$ and $\mathrm{TiO}_{2}$ are retained, and $\mathrm{Al}_{2} \mathrm{O}_{3}$ concentrations are nearly constant. In general, for fresh water alteration, $\mathrm{Na}$ and $\mathrm{K}$ are depleted, whereas these elements are retained in surface layers of samples altered in seawater. Clays are the most common authigenic

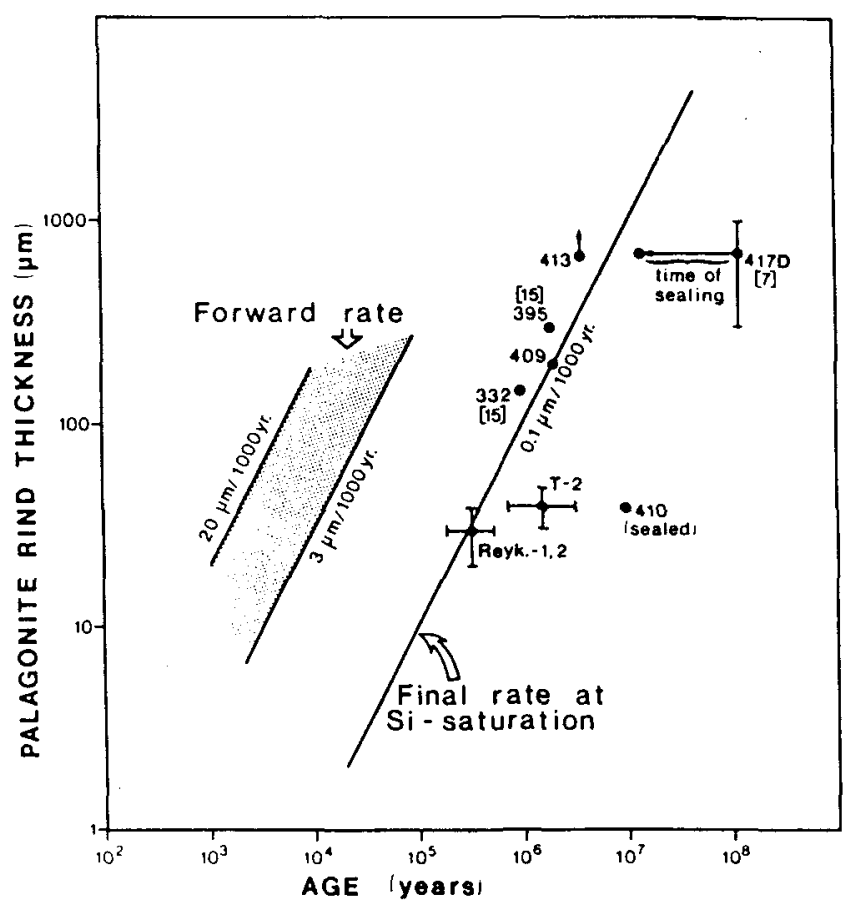

FIG. 7. Log-log plot of palagonite rind thickness as a measure of reaction rates versus age for basaltic glasses. minerals, replacing the altered layer. ${ }^{7,29}$ Zeolites are common in both fresh water- and seawater-altered basaltic glasses. Chabazite, $\mathrm{CaAl}_{2} \mathrm{Si}_{4} \mathrm{O}_{12} \cdot 6 \mathrm{H}_{2} \mathrm{O}$, is the most common zeolite.

The PHREEQE code was used to calculate the sequence of phase formation in basalt glass-seawater reactions. ${ }^{29}$ The calculated sequence nontronite/saponite/ phillipsite/chabazite is in agreement with the observed sequence palagonite/smectite (saponite)/phillipsite/ gyrolite/chabazite/analcime. Such an approach emphasizes the importance of metastable phases in controlling solution compositions: the sequence of clay mineral compositions (e.g., Fe-saponite versus $\mathrm{Mg}$-saponite) depended on whether ferrihydrite or the less soluble lepidocrosite was used in the calculations. Additionally, examination of natural glasses suggests that celadonite and chlorite are "kinetically hindered" phases and can be excluded from the list of potential alteration products used in the computational simulation of solution concentrations. These examples demonstrate that the selection of a reaction path for the long-term dissolution of a waste glass can be substantiated by experimental and field studies of alteration products of basalt glasses.

\section{EVALUATION OF THE LONG-TERM PERFORMANCE OF NUCLEAR WASTE GLASS}

The experimental and theoretical results have been used in an assessment of the long-term performance of the JSS-A glass. ${ }^{30}$ The corrosion results derived from the analysis of natural basaltic glasses were used to support the assumption that the rate, $r_{\infty}$, of the JSS-A glass is constant in the long term. A discussion of this modeling work can also be found in a study on the comparison of nuclear waste forms. ${ }^{36}$

Table VIII lists the parameters used in the calculation of the chemical durability of a large-scale glass block when in permanent contact with water at $90^{\circ} \mathrm{C}$. The parameters and data in Table VIII have been divided into three categories: (1) materials properties, (2) production-related waste form data, and (3) repository conditions. The temperature $\left(90^{\circ} \mathrm{C}\right.$ in this case) is not constant in a repository, but will approach ambient temperature (e.g., $15^{\circ} \mathrm{C}$ at $500 \mathrm{~m}$ depth in the case of a granitic environment in Sweden) when the heat of radioactive decay decreases. This will probably lower the reaction rate and thus the extent to which a glass block will be altered after, e.g., $10^{3} \mathrm{yr}$, relative to what is calculated here. A temperature dependence was not included in the calculations, because of uncertainties in the experimental determination of the long-term rate. The rate at $90{ }^{\circ} \mathrm{C}$ was already so small that it could barely be determined with the experimental techniques used in this project. Hence, the results reported here underestimate the chemical durability of the JSS-A 
(COGEMA) glass relative to that in a more realistic disposal scenario.

Glass block units of COGEMA size were considered $(150 \mathrm{~L}$ of glass in a stainless steel container). The glass in the canister was assumed to be fractured, with an increase in the surface area of a factor of ten. The volume of water in contact with the glass was assumed (conservatively) to be the void volume in the container, $0.02 \mathrm{~m}^{3}$. The flow rate of water was varied in the calculations between 0 and $100 \mathrm{~L} / \mathrm{yr}$ in order to study the response of the waste form to this variable, but under realistic repository conditions it should be on the order of $0.1 \mathrm{~L} / \mathrm{yr}$ (conservative value) or less.

Results ${ }^{30}$ of calculations with the GLAssol code are shown in Fig. 8. The figure shows the amount of some elements in solution relative to the initial, total inventory of that element in the glass block. Results for the "rate determining" element, $\mathrm{Si}$, and for a soluble element, $\mathrm{B}$, and two insoluble elements, $\mathrm{Fe}$ and $\mathrm{Al}$, have been plotted for flow rates of $0-10^{-5} \mathrm{~m}^{3} / \mathrm{h}(0-100 \mathrm{~L} / \mathrm{yr})$ as a function of time up to $\geqslant 10^{4}$ years after canister failure. The release of boron is only slightly affected by flow rate variations. The release of boron increases as soon as the flow rate is high enough to prevent silica saturation in the leachate (Fig. 8). At a flow rate of $10^{-7} \mathrm{~m}^{3} / \mathrm{h}, 95 \%$ of the silica and more than $99.9 \%$ of iron and aluminum are retained after $10^{4}$ years. At the highest flow rate, $10^{-5} \mathrm{~m}^{3} / \mathrm{h}$, only $50 \%$ of the silica and $90 \%$ of the aluminum, but $99.9 \%$ of the iron is retained. The $\mathrm{Al} / \mathrm{Fe}$ and $\mathrm{Si} / \mathrm{Fe}$ ratios in the surface layers decrease with decreasing residence time of the solution. The release curves do not vary linearly with the flow rate. For example, the 100 -fold increase in flow rate

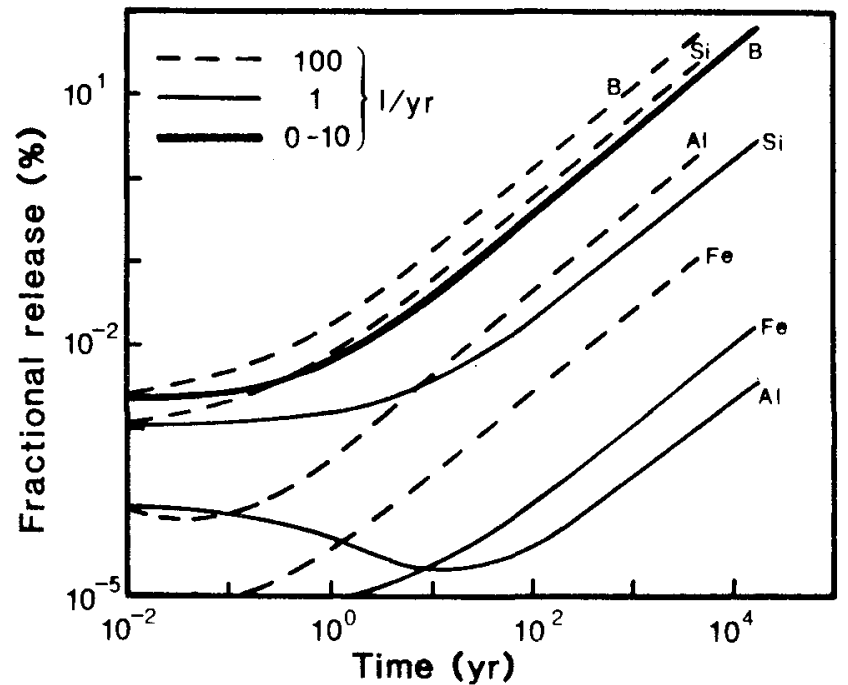

FIG. 8. Effect of flow rate on the predicted release of Si, B, Al, and $\mathrm{Fe}$ (de-ionized water, $90^{\circ} \mathrm{C}$ ) from borosilicate nuclear waste glass (JSS-A). The fractional release is the amount of the respective element in solution relative to that in the glass (for curve explanation see text and for waste form dimensions see Table VIII). leads to a 1000 -fold increase in the release of aluminum. The equilibrium concentration of aluminum in solution varies nonlinearly with the $\mathrm{pH}$ of the leachate, and the $\mathrm{pH}$ of the leachate is flow rate dependent. There are two limiting cases: (1) at flow rates high enough to prevent accumulation of glass corrosion products in the leachate, the $\mathrm{pH}$ equals that of the leachant, (2) at low enough flow rates and in a closed system the $\mathrm{pH}$ is controlled by the glass corrosion products.

Experimental uncertainties in critical data values, such as the exact silica saturation concentration and the long-term corrosion rate, require that additional confidence in the calculations be provided in order to evaluate the results of a performance assessment. This can be done by studying the effect on the results of variations in the critical parameters and by the use of bounding type calculations. In Fig. 9, five cases are presented which demonstrate the range of potential glass performance depending on the release mechanism. ${ }^{30}$ The fraction of glass altered is plotted versus corrosion time.

In the following discussion, comparisons will be made with reference to curve (b) which is based on the experimental data and which was calculated for a flow rate of $1 \mathrm{~L} / \mathrm{yr}$ and $r_{\infty}=0.0025 \mathrm{~g} \cdot \mathrm{m}^{-2} \mathrm{~d}^{-1}$. The flow rate was kept constant in all cases. Curve (a) shows the glass alteration process if the forward rate was rate determining. This is a hypothetical case as discussed above, and a bounding case because the calculated values cannot be exceeded at $90{ }^{\circ} \mathrm{C}$ in an infinite solution volume or at unrealistically high flow rates.

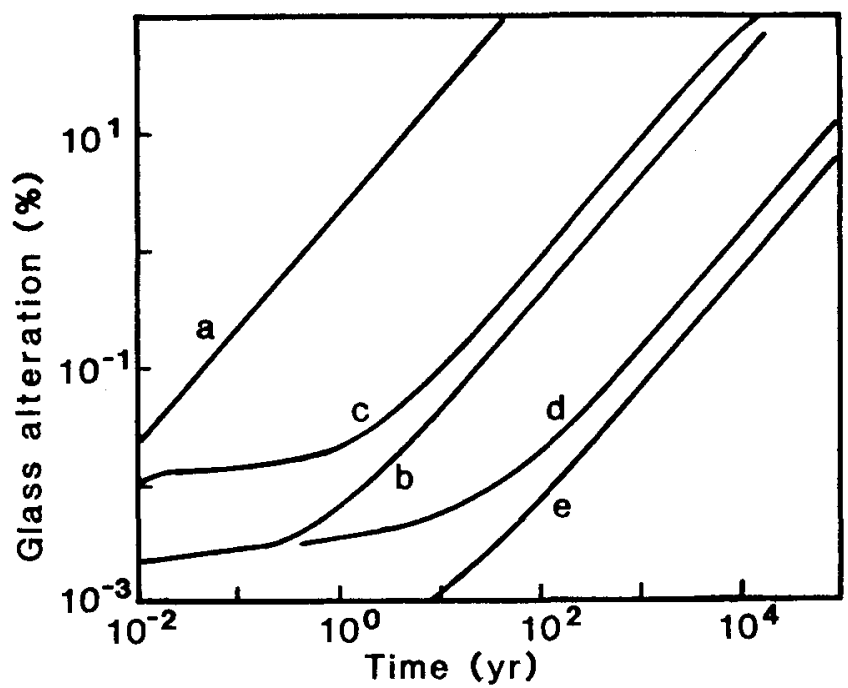

FIG. 9. Prediction of borosilicate nuclear waste glass (JSS-A) corrosion as a function of exposure time for different release mechanisms. (a) Controlled by the forward rate (Table VIII); (b) controlled by the long-term rate (Table VIII), flow rate is $1 \mathrm{~L} / \mathrm{yr}$; (c) as in (b) but the long-term rate increased by a factor of two and amorphous silica saturation allowed; (d) long-term rate equals zero; i.e., release is flow-rate controlled; (e) as in (d) but the near-field effect considered. 
The actual alteration rate will be much less under realistic repository conditions. Curve (c) was obtained when the silica concentration was allowed to approach the saturation value for amorphous silica which is five times higher than the silica saturation value for the glass surface, $\log K=-2.94$, used in case (b). Additionally, a higher long-term rate, $R_{\infty}=0.005 \mathrm{~g} \cdot \mathrm{m}^{-2} \mathrm{~d}^{-1}$, a value slightly higher than that derived from the corrosion tests in the Stripa mine by Hench et al. ${ }^{32}$ was taken. The higher silica saturation value gives a higher 'initial' alteration rate because more silica is required to reach saturation in solution. The increase of the final rate by a factor of two in case (c) relative to (b) leads to a parallel shift of the curve. Lower, but constant, alteration rates extend the plateau in (b) to longer times and then yield curves parallel to (b) but not below (d). Cases (d) and (e) were calculated assuming that the corrosion reaction ceases after silica saturation of the solution with respect to the glass surface. This means that further alteration of the glass could occur only as a result of flow. Curve (d) can also be obtained when the longterm rate is not zero but small compared with the rate at which silica is removed from the system. Barkatt et $a l^{33}$ consider case (d) as limiting the corrosion of glass. At this point, glass alteration is determined by the flow rate and no longer by the long-term corrosion rate. With decreasing flow rate (lower than $10^{-7} \mathrm{~m}^{3} / \mathrm{h}$ ), the limiting curve (d) moves farther to the right below (b) until the long-term rate determines the position of the alteration curve. If the flow rate becomes zero, e.g., in temporarily or permanently sealed systems, glass alteration-after Grambow's model ${ }^{5}$ - would still proceed because of the long-term rate in the presence of water.

Case (e) describes the situation when effects from the area closest to the glass in a geologic nuclear waste repository determine the alteration rate. A $1 \mathrm{~m}$ thick backfill of bentonite around the glass was assumed, and a diffusion coefficient of silicic acid in the bentonite of $10^{-6} \mathrm{~m}^{2} / \mathrm{d}$ was used in the calculation. This curve (e) constitutes the lower limit for glass alteration among the case studies. The control of glass alteration by nearfield effects was considered by Zavoshy et al. ${ }^{31}$ The rate equation given by these authors is similar to that used in GLASSOL, ${ }^{5}$ if (1) there is no long-term rate, (2) the silica concentration outside the bentonite is zero, (3) solubility limits are not $\mathrm{pH}$ dependent, and (4) the solubility of elements such as boron is the same as that of silica. The implications of these limitations will not be discussed here in detail, but, e.g., curve (b) in Fig. 9-which is based on the existence of a long-term corrosion rate-and the curves for iron and aluminum in Fig. 8-which does include pH-dependent solubilities - cannot be calculated with these limitations. Zavoshy et al.'s model ${ }^{31}$ calculates the lower limit for the glass alteration rate and the release of soluble elements from the glass into solution.

For long-term contact with water, lower alteration rates than those leading to curve (e) cannot be substantiated. Even if the long-term rate were several orders of magnitude lower at lower temperatures, diffusive and convective transport of silica away from the glass may still control the alteration rate. This emphasizes the paramount role of silica as the stabilizing or destabilizing species for borosilicate nuclear waste glass in contact with water.

\section{SUMMARY AND CONCLUSIONS}

\section{A. Comparison of simulated and radioactive glass}

The dissolution behavior of the radioactive glass JSS-A was similar to that of the inactive simulated waste glasses R7T7 and ABS-118 for the short-term, transient period. Also, the long-term corrosion rate was found to be similar for the radioactive and the inactive glass.

The release of actinoids $(\mathrm{Pu}, \mathrm{Am})$ from the radioactive glass was always less than $1 \%$ that of the $\mathrm{B}$ release. The soluble fraction of $\mathrm{Pu}$ (about $10^{-9} \mathrm{M}$ ) was found to be independent of experimental conditions and indicated solubility control by an insoluble Pu compound. The release of actinoids from the glass was not limited by solubility because of colloid formation.

\section{B. Data evaluation}

An extensive data base was created which allowed the description of the corrosion behavior of COGEMA type glasses as a function of water composition, $\mathrm{pH}$ value, temperature, sample surface area, solution volume, and flow rate, with and without the presence of bentonite and/or steel corrosion products for times up to 1.5 years.

After silica saturation was attained, the corrosion rate (in the order of $10^{-3} \mathrm{~g} \cdot \mathrm{m}^{-2} \mathrm{~d}^{-1}$, with and without bentonite) was about a factor of 1000 lower than the rate prior to silica saturation, which was $1.5 \mathrm{~g} \cdot \mathrm{m}^{-2} \mathrm{~d}^{-1}$.

When bentonite was present, the initial normalized mass loss of soluble elements varied with the amount of bentonite present (Table IV-A). The long-term rate was unaffected by the presence of bentonite.

In the presence of magnetite, the long-term rate was approximately five times higher than in de-ionized water. The increase could be explained by the slow formation of iron silicates or by multi-layer sorption of silica on the surface of magnetite.

An effect of temperature on the long-term rate could not be determined, because the precision of the experimental data was not sufficient. 
A computer program, GLASSOL, was developed, based on a dissolution/precipitation model, to calculate the glass water reaction. Fair agreement between observations and the model calculations was achieved.

\section{Evaluation of the long-term performance of COGEMA type glass}

The GLASSOL code was used to assess the long-term performance of COGEMA type glass in a repository of granitic rock with a waste environment characterized by a steel overpack and bentonite.

Use of a constant (time-independent) long-term rate was justified by observations on basaltic glasses of great age, which were compatible with what was inferred from experiments with nuclear waste glasses in the laboratory. This type of rate was considered as an upper limit for the alteration of the glass.

As a result of the calculations, a fractured glass block would not be fully altered within 10000 years at $90{ }^{\circ} \mathrm{C}$ (flow rate $<100 \mathrm{~L} / \mathrm{yr}$ ). At $50{ }^{\circ} \mathrm{C}$, the durability may be greater. On the other hand, it is unlikely that for long-term contact with groundwater the glass block would remain intact for time periods longer than 1 million years under repository conditions.

The long-term rate controls the release of soluble elements. The release of sparingly soluble glass constituents was lower and was controlled by the flow rate but was not proportional to it.

The chemical effect of bentonite on the durability of the glass matrix was of minor importance for the evaluation of its long-term alteration, but sorption of radionuclides such as Cs significantly reduces their concentrations in contacting groundwater.

The effect of magnetite on glass corrosion depended on the corrosion rate of the steel canister and/or the rate of iron silicate formation or multi-layer silica sorption.

\section{ACKNOWLEDGMENTS}

The JSS Project owes its results to the experimental and modeling work of the several laboratories involved as well as to the efforts of their participating scientists and technicians. During the project, the research program and the results have been reviewed by a Technical Advisory Group consisting of Dr.W. Lutze (chairman) HMI, Dr. D. M. Strachan, PNL, Dr.H.U. Zwicky, PSI, Dr. J.C. Alder, NAGRA, Dr. N. JacquetFrancillon, CEA-Marcoule, Dr. N. Yoshiki, CRIEPI, and Dr. L. O. Werme, SKB, and, during initial phases of the project, also Dr.G. Bart, PSI, Dr. L.L. Hench, University of Florida, and Dr. H. Koyama, CRIEPI.

\section{REFERENCES}

${ }^{1}$ JSS-Projekt Phase I, SKB, Stockholm, Sweden, Technical Report 84-03 (1984).
${ }^{2}$ JSS-Projekt Phase II, SKB, Stockholm, Sweden, Technical Report 85-01 (1985).

${ }^{3}$ JSS-Projekt Phase III, SKB, Stockholm, Sweden, Technical Report 86-01 (1986).

${ }^{4}$ JSS-Projekt Phase IV, SKB, Stockholm, Sweden, Technical Report 87-01 (1987).

${ }^{5}$ B. Grambow, SKB, Stockholm, Sweden, Technical Report 87-02 (1987).

${ }^{6}$ JSS-Projekt Phase V, SKB, Stockholm, Sweden, Technical Report 88-02 (1988).

${ }^{7}$ M. J. Jercinovic and R. C. Ewing, SKB, Stockholm, Sweden, Technical Report 88-01 (1987).

${ }^{8}$ M. Müller-Vonmoos and G. Kahr, Technischer Bericht 83-12, Nagra, Baden, Switzerland (1983).

${ }^{9}$ Anon., MCC-1P Static Leach Test Method, Nuclear Waste Materials Handbook, DOE/TIC-11400 (1981).

${ }^{10}$ Anon., MCC-4S Low-Flow-Rate Leach Test Method, Nuclear Waste Materials Handbook, PNL-3990 (1981).

${ }^{11}$ G. Bart, E.T. Aerne, and H. U. Zwicky, Nucl. Instr. Methods B17, 127 (1986)

${ }^{12}$ B. Grambow, Ph.D. Thesis, Freie Universität Berlin (1984), English transl. by E.I. du Pont de Nemours \& Co., Aiken, SC, DP-tr-78 (1985).

${ }^{13}$ W. L. Kuhn and R. D. Peters (Proc. Mater. Res. Soc. Symp.), edited by D. G. Brookins (North-Holland, New York, 1983), Vol. 15, p. 167.

${ }^{14}$ R. M. Wallace and G. G. Wicks (Proc. Mater. Res. Soc. Symp.), edited by D. G. Brookins (North-Holland, New York, 1983), Vol. 15, p. 23.

${ }^{15}$ A. Barkatt, J. H. Simmons, and P. B. Macedo, Nucl, and Chem. Waste Management 2, 3 (1981).

${ }^{16}$ P. Aagaard and H. C. Helgeson, Amer. J. Science 281, 237 (1982). ${ }^{17}$ G. G. Wicks, J. A. Stone, G.T. Chandler, and S. Williams, Report DP-1728 (1986).

${ }^{18}$ W. Lutze, R. Müller, and W. Montserrat (Proc. Mater. Res. Soc. Symp.) (Materials Research Society, Pittsburgh, PA, 1988), Vol. 112, p. 575.

${ }^{19}$ D. L. Park hurst, D. C. Thorstensen, and L. N. Plummer, PHREEOE, Water-Resources Investigations 80-96 (U.S. Geological Survey, Reston, VA), 1980. Extension to run precipitation controlled reactions by P. Offermann, HMI, Berlin, FRG (1983), updated with the MinteQ data base by W. Howden and K. Kruppka, PNL, Richland, WA (1984).

${ }^{20}$ B. Fritz and M. Kam, SKB Stockholm, Sweden Technical Report 85-10 (1985).

${ }^{21}$ H. Wanner (Proc. Mater. Res. Soc. Symp.), edited by L. O. Werme (Materials Research Society, Pittsburgh, PA, 1986), Vol. 50, p. 509.

${ }^{22}$ F. Lanza and C. Ronsecco (Proc. Mater. Res. Soc. Symp.), edited by W. Lutze (Materials Research Society, Pittsburgh, PA, 1982), Vol. 11, p. 173.

${ }^{23}$ G. L. McVay and C. Q. Buckwalter, J. Am. Ceram. Soc. 66, 170 (1983).

${ }^{24}$ J.W. Shade, L. R. Pederson, and G. L. McVay, Advances in Ceramics VIII, edited by G. G. Wicks and W. A. Ross (The Am. Ceram. Soc., Columbus, OH, 1983), p. 358.

${ }^{25}$ G. Malow, W. Lutze, and R. C. Ewing, J. Non-Cryst. Solids 67, 305 (1984).

${ }^{26}$ W. Lutze, G. Malow, R. C. Ewing, M. Jercinovic, and K. Keil, Nature 314, 252 (1985).

${ }^{27}$ R. C. Ewing and M. J. Jercinovic (Proc. Mater. Res. Soc. Symp.), edited by J. K. Bates and W. B. Seefeldt (Materials Research Society, Pittsburgh, PA, 1987), Vol. 84, p. 67.

${ }^{28}$ S. P. Jakobsson and J. G. Moore, Geological Society of America Bulletin 97, 648 (1986).

${ }^{29}$ B. Grambow, M. J. Jercinovic, R. C. Ewing, and C. D. Byers 
(Proc. Mater. Res. Soc. Symp., 1986), edited by L. O. Werme, Vol. 50, p. 263.

${ }^{30}$ B. Grambow, W. Lutze, R. C. Ewing, and L. O. Werme (Proc. Mater. Res. Soc. Symp., 1986), edited by M. J. Apted and R. E. Westerman, Vol. 112, p. 531.

${ }^{31}$ S. J. Zavoshy, P. L. Chambré, and T. H. Pigford (Proc. Mater. Res. Soc. Symp., 1985), edited by C. M. Jantzen, J. A. Stone, and R. C. Ewing, Vol. 44, p. 311.

${ }^{32}$ L. L. Hench, L. O. Werme, and A. Lodding (Proc. Mater. Res. Soc. Symp., 1982), edited by W. Lutze, Vol. 11, p. 153.

${ }^{33}$ A. Barkatt, P. B. Macedo, B. C. Gibson, and C. J. Montrose
(Proc. Mater. Res. Soc. Symp., 1985), edited by C. M. Jantzen, J. A. Stone, and R. C. Ewing, Vol. 44, p. 3.

${ }^{34}$ B. Grambow (Proc. Mater. Res. Soc. Symp., 1985), edited by C. M. Jantzen, J. A. Stone, and R. C. Ewing, Vol. 44, p. 15.

${ }^{35} \mathrm{~W}$. Lutze, in Radioactive Waste Forms for the Future, edited by W. Lutze and R.C. Ewing (North-Holland, Amsterdam, 1988), pp. 123-130.

${ }^{36}$ W. Lutze and R.C. Ewing, in Radioactive Waste Forms for the Future, edited by W. Lutze and R. C. Ewing (North-Holland, Amsterdam, 1988), pp. 699-740. 